\title{
Signaling in Equity Crowdfunding
}

\author{
Gerrit K.C. Ahlers, ${ }^{*}$ \\ Douglas Cumming, ${ }^{\dagger}$ \\ Christina Günther, ${ }^{\ddagger}$ \\ Denis Schweizer $\$$
}

\begin{abstract}
This paper presents an empirical examination of which start-up signals will small investors to commit financial resources in an equity crowdfunding context. We examine the impact of firms' financial roadmaps (e.g., preplanned exit strategies such as IPOs or acquisitions), external certification (awards, government grants and patents), internal governance (such as board structure), and risk factors (such as amount of equity offered and the presence of disclaimers) on fundraising success. Our data highlight the importance of financial roadmaps and risk factors, as well as internal governance, for successful equity crowdfunding. External certification, by contrast, has little or no impact on success. We also discuss the implications for successful policy design.
\end{abstract}

JEL Classification: $\quad$ G21, G24, L26

Keywords: Entrepreneurial Finance, (Equity) Crowdfunding, Micro Lending, Internet, Signaling

\footnotetext{
* A.T. Kearney GmbH, Charlottenstraße 57, 10117 Berlin, Germany, e-mail: Gerrit.Ahlers@atkearney.com.

† Professor and Ontario Research Chair, York University - Schulich School of Business, 4700 Keele Street, Toronto, Ontario M3J 1P3, Canada, Web: http://ssrn.com/author=75390, Phone: +1-416-736-2100 ext 77942, Fax: +1-416-736-5687, e-mail: dcumming@schulich.yorku.ca.

${ }^{\ddagger}$ Max Planck Institute of Economics, Kahlaische Str. 10, 07745 Jena, Germany \& WHU - Otto Beisheim School of Management, Assistant Professor of Industrial and Innovation Economics, Burgplatz 2, 56179 Vallendar, Germany, Phone: +49 3641686 825, Fax: +49 3641686 868, e-mail: guenther@econ.mpg.de.

$\S$ WHU - Otto Beisheim School of Management, Assistant Professor of Alternative Investments, Burgplatz 2, 56179 Vallendar, Germany, Phone: +49 261 - 6509 724, Fax: +49 261 - 6509 729, e-mail: Denis.Schweizer@whu.edu.
} 


\title{
Signaling in Equity Crowdfunding
}

\begin{abstract}
This paper presents an empirical examination of which start-up signals induce small investors to commit financial resources in an equity crowdfunding context. We examine the impact of firms' financial roadmaps (e.g., preplanned exit strategies such as IPOs or acquisitions), external certification (awards, government grants and patents), internal governance (such as board structure), and risk factors (such as amount of equity offered and the presence of disclaimers) on fundraising success. Our data highlight the importance of financial roadmaps and risk factors, as well as internal governance, for successful equity crowdfunding. External certification, by contrast, has little or no impact on success. We also discuss the implications for successful policy design.
\end{abstract}

JEL Classification: G21, G24, L26

Keywords: Entrepreneurial Finance, (Equity) Crowdfunding, Micro Lending, Internet, Signaling 
Crowdfunding is an umbrella term used to describe an increasingly widespread form of fundraising whereby groups of people pool money, typically (very) small individual contributions, to support a particular goal. Despite increased attention by policymakers, regulators, investors, and founders, however, the mechanisms and dynamics of crowdfunding in general, and equity crowdfunding in particular, are not yet well understood (Griffin, 2012).

Equity crowdfunding is a form of financing in which entrepreneurs make an open call for funding on the Internet, hoping to attract a large group of investors. The open call and the investments take place on an online platform (such as, e.g., Crowdcube) that provides the means for the transactions (the legal groundwork, pre-selection, the ability to process financial transactions, etc.). In recent years, the equity branch of crowdfunding has become an increasingly important financing alternative for start-ups, and volume has doubled every year since 2009. In 2011, start-ups worldwide raised U.S. \$88 million through equity crowdfunding platforms (Crowdfunding Industry Report, 2012).

Given the recent passage of the JOBS (Jumpstart Our Business Startups) Act in the U.S., which will permit equity crowdfunding by early 2013, this number is likely to increase sharply. Small investors, who are often the primary support of start-ups, do not usually have the capability to extensively research and assess potential investments. In order to successfully raise money via an equity crowdfunding platform, therefore, start-ups need to find ways to clearly signal their value to small investors.

Two contrasting London-based crowdfunding cases illustrate the issues discussed further here. In December 2011, The Rushmore Group, a start-up that now operates three bars in London, sold $10 \%$ of its equity for $£ 1,000,000$ to 143 small investors through Crowdcube. The aspiring entrepreneurs of The Rushmore Group accomplished this feat in a little over two weeks - a remarkable success story.

A strikingly different outcome, however, is illustrated by our second example. In early April 2012, another owner and operator of a London bar, Meatballs, offered a 25\% equity 
stake for $£ 300,000$ on Crowdcube. Two months after the start of the offering, they had raised only $£ 4,750$.

The Rushmore Group and Meatballs perform essentially the same service in the same city. Both start-ups were presented in the same fashion and on the same online platform. Why, then, did the equity offering of The Rushmore Group succeed while that of Meatballs failed? The comparison of these two cases gives rise to the central question of our paper: Given different start-ups with similar observable characteristics, what leads small investors to invest in certain start-ups and not in others?

It seems that potential investors try to evaluate the unobservable characteristics of start-ups by interpreting the signals sent by entrepreneurs (Connelly et al., 2011). In a similar context, signaling theory (as per, e.g., Spence, 1973) has been used to explain which types of information (board characteristics, top management team characteristics, the presence of venture capitalists or angel investors, founder involvement, etc.) lead investors to invest in start-ups (Goldfarb et al., 2007; Nahata, 2008; Cosh, Cumming and Hughes, 2009; Agrawal et al., 2010; Robb and Robinson, 2012; Cole and Sokolyk, 2012). This stream of literature has focused predominantly on the signaling of young start-ups toward angel investors or venture capitalists (e.g., Hsu, 2004). There is, however, little research on the signaling of start-ups toward small investors.

The way young start-ups signal to small investors is likely to be different from the way they would signal to angels or venture capitalists. The corporate finance literature defines small investors as those who 1) invest relatively small amounts of money, and 2) receive a relatively small stake of a company in return (e.g., Malmendier and Shanthikumar, 2007). Small investors are likely to lack the financial sophistication and experience of angel investors or venture capitalists, who are generally highly knowledgeable about valuing start-ups and assessing founding teams (Freear, Sohl and Wetzel, 1994). Furthermore, relative to their investments, the costs for angel investors and venture capitalists to evaluate ideas and teams 
are fairly small, but they would be prohibitively high for small investors. For example, it would not make economic sense for a potential investor to spend weeks evaluating the due diligence of a start-up investment that may only yield an amount equal to several days' salary.

This paper presents an initial empirical examination of which start-up signals are most likely to induce small investors to commit financial resources in an equity crowdfunding context. We examine 104 offerings between October 2006 and October 2011 based on data from one of the largest equity crowdfunding platforms, ASSOB (the Australian Small Scale Offerings Board). We believe this platform is very suitable for our purpose because of its size and its location in Australia, a country that permits equity crowdfunding.

We examine data on the number of investors per project, the amount of capital raised, and the speed (length of time) of capital-raising in an effort to understand the value of the different signals of potential project quality. We find that start-ups with more board members, higher levels of education (as measured by the percentage of board members holding an MBA degree), and better networks are more likely to attract investment and to have a higher number of investors. We also note that start-ups that signal their intention to seek an exit by either IPO or a trade sale are more likely to attract investors than those planning to use other forms of exit. Moreover, firms that provide neither financial forecasts nor disclaimers are less likely to attract investors, and they tend to raise less capital overall and over a longer amount of time. Firms that have been in business longer prior to seeking equity crowdfunding are also more likely to raise their desired level of capital more quickly.

This paper adds to the limited extant empirical literature on crowd financing (e.g., Schwienbacher and Larralde, 2010; Agrawal, Catalini and Goldfarb, 2011; Burtch, Ghose, and Wattal, 2012; and Mollick, 2012), and our dataset enables us to draw conclusions about equity crowdfunding before it formally opens to U.S. investors. The evidence can thus offer important insights not only for investors and founders but also for regulators prior to the JOBS Act becoming effective. 
The remainder of the paper proceeds as follows. Section I provides a discussion of the institutional setting, while section II describes our data. Section III presents the theoretical background and empirical evidence. Section IV summarizes our main results, discusses the policy implications, and concludes.

\section{Institutional Background of Equity Crowdfunding}

In this section, we introduce the concept of equity crowdfunding as a new form of start-up financing. Section A gives a general outline, and highlights the salient differences between equity crowdfunding and other types of crowdfunding such as donations. Section B then provides an overview of the equity crowdfunding market.

The market data and examples in section A were collected for the Crowdfunding Industry Report (2012), a general market analysis conducted in the first quarter of 2012 by Crowdsourcing.org. The survey yielded over 170 responses from a total of 452 active crowdfunding platforms. Of these, 135 submissions were comprehensive and complete, and we obtained extensive data on volume, operations, and key constituents (e.g., funders and fundraisers) for the calendar years 2009, 2010, and 2011 (for further information, see also Forbes Magazine, 2012).

\section{A. From Crowdfunding to Equity Crowdfunding}

As we noted at the outset, the umbrella term "crowdfunding” encompasses various types of fundraising that can range from collecting donations to selling equity stakes via the Internet. But a clear definition of the term has yet to be proposed. One definition comes from Hemer (2011), who defines crowdfunding as an "open call, essentially through the Internet, for the provision of financial resources either in form of donations (without rewards) or in exchange 
for some form of reward and/or voting rights in order to support initiatives for specific purposes”. Belleflamme, Lambert and Schwienbacher (2012) offer a similar definition.

The focus of crowdfunding can vary greatly, both in goals, such as political campaigns (Barack Obama raised over \$100 million in small contributions during the 2008 presidential election), charities, or art projects, and in magnitude. Donations can range from $\$ 1$ to several millions of dollars in entrepreneurial seed financing.

Politicians in the U.S., seeking new routes to stimulate the economy, have favored small business and new venture creations (see the 2011 JOBS Act, as well as the Entrepreneur Access to Capital Act). However, such efforts often require external financing, which can be difficult to obtain at the initial stage via bank loans or equity capital. Thus, companies may find themselves either unfunded, or funded with a less than preferable source of capital (see, for example, Cosh, Cumming and Hughes, 2009; Robb and Robinson, 2012; and Cole and Sokolyk, 2012). To bridge this gap, politicians are suggesting new, more modern means of capital formation.

As noted above, the variety of crowdfunding systems is broad, and ranges from equity, lending, and reward-based methods to outright donations. Among these alternatives, equity crowdfunding, where a group of small investors provides young start-ups with funding in exchange for shares in the company, may be one of the most promising ways to increase small business growth. President Obama signed the JOBS Act on April 5, 2012, legalizing equity crowdfunding in start-ups by so-called “non-accredited” investors by early 2013.

The funding process on most crowdfunding platforms is similar, regardless of the type of crowdfunding used. It begins with a fundraiser initiating a request for funding, typically by indicating what the money is needed for, and what, if anything, is offered in exchange. Potential investors can browse the offers, and, if interested, invest a small amount (generally a few dollars) toward the target amount. The crowdfunding website provides the technical platform for the exchange of funds, voting rights, etc. 
The categorization of the four main types of crowdfunding (donation-based, reward-based, lending, and equity $)^{1}$ is based on what, if anything, investors receive for their contributions. But the legal complexity and the degree of information asymmetry between fundraiser and investor differ significantly depending on the type of crowdfunding (see Figure 1).

For example, in donation-based crowdfunding, funders donate to causes they want to support, with no expectation of monetary compensation. This can also be considered a philanthropic or sponsorship-based incentive. This form of funding is not complex from a legal standpoint. Furthermore, the degree of uncertainty is less important than it would be for other types of crowdfunding, because donors presumably already have a positive opinion of the organization. An example of a donations crowdfunding platform is Fundly, ${ }^{2}$ which allows individuals and organizations to create an online fundraiser solely for the purpose of collecting donations.

In contrast, reward-based crowdfunding offers funders a non-financial benefit in exchange for their investment. A prominent example of this type of platform is Kickstarter. Kickstarter allows fundraisers to raise money by offering non-monetary rewards in return for financial support. For example, a team of product developers raised over U.S. $\$ 10$ million $^{3}$ on Kickstarter by pre-selling an e-paper watch at a discounted price.

Lending crowdfunding is another model, where funders receive fixed periodic income and expect repayment of principal. Lending crowdfunding platforms, such as Prosper, generally facilitate peer-to-peer loans. In other words, individuals receive loans directly from other individuals.

\footnotetext{
1 This categorization is similar to that used by other authors. For example, Hemer (2011) distinguishes "sponsoring” as a fifth category, alongside "donations," "pre-purchasing” (i.e., reward-based), "lending," and "equity.” Bradford (2012) cites "donation sites,” "reward and pre-purchase sites,” "lending sites,” and "equity sites.” Within the lending sites category, he further differentiates between "sites not offering interest," and "sites offering interest."

${ }^{2}$ More detailed information about the crowdfunding platforms mentioned here can be found at: http://fundly.com/about-us, http://www.kickstarter.com/help/faq/kickstarter\%20basics\#WhatIsKick, http://www.prosper.com/about/, and http://assob.com.au/about.asp?page=1.

${ }^{3}$ As of June 30, 2012 (http://www.kickstarter.com/projects/597507018/pebble-e-paper-watch-for-iphone-andandroid).
} 
The last model is equity crowdfunding, in which investors receive some form of equity or equity-like arrangements (e.g., profit-sharing) in the venture they support. As mentioned earlier, ASSOB is one of the most prominent equity crowdfunding platforms. It enables entrepreneurs to sell equity shares to small investors. For example, an Australian high-tech start-up sold approximately 10\% of its equity on ASSOB for AUD 630,000 (approximately U.S. \$645,000) to twenty-three small investors in 2009.

We believe that equity crowdfunding is the most relevant empirically for studying entrepreneurial signaling to small investors. This is in contrast to donations crowdfunding, where factors other than potential monetary returns are important for funders, which makes a meaningful comparison among crowdfunding types difficult. Therefore, information asymmetries surrounding the entrepreneur's or start-up's ability to generate future cash flows are less important in this context.

Similarly, reward-based crowdfunding is less suitable for our purpose because funders receive a product rather than a share in a company in return for their financial contributions. Funders must evaluate an entrepreneur's ability to produce and deliver a pre-purchased product, and we thus believe that reward-based crowdfunding would be more suitable empirically for a pre-purchasing study (for similar arguments, see also Belleflamme, Lambert and Schwienbacher, 2010).

However, lending crowdfunding could be somewhat appropriate for an empirical analysis of signaling, but prior research has questioned whether the essential signal in lending crowdfunding is a company’s credit information (Lin, Prabhala and Viswanathan, 2009). And reliable signals are not typically available from start-ups, because they may not have a credit history yet.

\section{- Figure 1 about here-}

The term "equity crowdfunding" has not been specifically defined in previous research. Bradford (2012) explains equity crowdfunding as a model in which funders receive an interest 
in the form of equity or equity-like arrangements (e.g., profit-sharing) in the ventures they fund. Hemer (2011) points out that the central difference between equity crowdfunding and traditional capital-raising is the funding process itself: Entrepreneurs make an open call for funding on a crowdfunding platform, and investors make their decisions based on the information provided therein. Moreover, the crowdfunding platform facilitates the transaction by providing a standardized investment contract and settling the payments. Hemer (2011) also notes that individual equity crowdfunding investments in start-ups are generally much smaller than venture capital or angel investments.

Combining these insights, we define equity crowdfunding as follows: Equity crowdfunding is a method of financing whereby an entrepreneur sells equity or equity-like shares in a company to a group of (small) investors through an open call for funding on Internet-based platforms.

\section{B. An Overview of the Equity Crowdfunding Market}

The equity crowdfunding market is substantially influenced by the legislative environment of its country. Furthermore, because it involves the sale of a security (Bradford, 2012), and is thus subject to various regulatory issues, equity crowdfunding has been restricted until now in many countries, such as the U.S. To date, the U.K., Ireland, France, the Netherlands, Switzerland, and Australia are the only OECD countries in which crowdfunding platforms are permitted to sell equity shares to small investors. But, as mentioned earlier, the U.S. is expected to deregulate equity crowdfunding by $2013,{ }^{4}$ and this is expected to have a sizeable impact on the equity crowdfunding market (The Economist, 2012).

\footnotetext{
${ }^{4}$ The JOBS Act stipulates that entrepreneurs can raise money from all potential investors; however, start-ups are limited to U.S. \$1 million per year, and must raise money through portals approved by the Securities and Exchange Commission. Moreover, the legislation dispenses with the 500-shareholder rule, which limited the number of shareholders a company was allowed to admit before going public (see Empson, 2012).
} 
Despite the regulatory restrictions, most legislative frameworks in OECD countries allow for certain revenue and profit-sharing arrangements. A number of platforms therefore operate in countries where the sale of voting shares through crowdfunding platforms is prohibited, but where profit-sharing is allowed. For example, the German crowdfunding platforms Seedmatch and Innovestment facilitate the sale of silent partnerships (Stille Beteiligung) through crowdfunding platforms. A silent partnership is an equity-like share in a company that gives investors a predefined share of profits but no voting rights. Moreover, the sale of voting rights through crowdfunding platforms is not permitted in Germany, but the sale of silent partnerships is permitted. ${ }^{5}$

As of April 2012, there were a total of thirty-nine ${ }^{6,7,8}$ crowdfunding platforms that facilitate equity crowdfunding or revenue-sharing models, which is $7.3 \%$ of the 452 total crowdfunding sites in existence (see Figure 2). Of these thirty-nine platforms, six offer unconventional revenue-sharing models for investments in music (e.g., My Major Company), films (e.g., Pirate My Film and Slated), arts in general (Sokap), or mobile applications (Appbackr and AppsFunder). The remaining thirty-three enable entrepreneurs and small enterprises to offer equity or equity-like shares in their companies to a large pool of small investors through open calls for funding on the Internet.

Eleven equity crowdfunding platforms are based in the U.S. (the California Stock Exchange, Cofolio, CrowdBackers, CrowdFundingBank, Junto, MicroVentures, RevenueTrades, Rippple, Sprigster, WealthForger, and Vim Funding), six are in France (Anaxago,

\footnotetext{
${ }^{5}$ Presumably, the German government created this loophole to enable informal and less expensive individual investment in start-ups and small and medium-sized companies without decreasing general investor protection in the equity market.

${ }^{6}$ According to the Massolution directory of sites. Massolution is a research and advisory firm specializing in the crowd sourcing and crowdfunding industries. As an industry analyst, Massolution tracks both the supply and demand side of each segment. Massolution also edited the Crowdfunding Industry Report (2012).

${ }^{7}$ Several other crowdfunding platforms, such as Sellaband, also facilitate revenue-sharing agreements. However, the focus of these sites is generally the facilitation of pre-purchasing, which generally means the pre-selling of music albums to finance their production. The pre-selling aspect is more important in these cases, and thus the author categorizes them as reward-based platforms.

${ }^{8}$ Additional equity crowdfunding sites are in the process of being launched. For example, Deutsche Venture Exchange (www.devexo.com) was recently launched in Germany.
} 
Buzz Entrepreneur, Cap Angel, Finance Utile, McKenson Invest, WiSeed), three in the Netherlands (CrowdAboutNow, Symbid, WeKomenErWel), three in Germany (Innovestment, Mashup Finance, Seedmatch), two in Australia (ASSOB, Project Powerup), two in the U.K. (Crowdcube, Grow VC), one in Spain (SeedQuick), and one each in Switzerland (C-crowd), Belgium (Mymicroinvest), Canada (Podium Ventures), Ireland (SeedUps), and Finland (Venture Bonsai).

\section{- Figure 2 about here-}

In 2011, the total funding volume of equity crowdfunding platforms was approximately U.S. $\$ 88$ million (see Figure 3). 93\% of this volume was raised on five platforms: SeedUps (approximately U.S. \$40 million), ASSOB (U.S. \$19 million), Grow VC (U.S. \$11 million), Buzz Entrepreneur (U.S. \$8 million), and Crowdcube (U.S. \$4 million). Therefore, most of the volume occurred on sites based in Ireland, Australia, the U.K., and France. However, average funding amount per project varied significantly, with U.S. \$200,000 for SeedUps, AUD 339,000 (U.S. \$347,000) for ASSOB, U.S. \$7,000 for GrowVC, U.S. \$136,000 for Buzz Entrepreneur, and GBP 188,000 (U.S. \$250,000) for Crowdcube. Other platforms, such as Innovestment and Seedmatch, tend to have relatively high average project volumes.

- Figure 3 about here - 


\section{Data Sample}

In this section, we introduce the ASSOB platform as the source of our sample. ASSOB, the Australian platform, has been in business since 2006. With AUD 125 million funded as of April 2012, it is also the equity crowdfunding platform that has raised the largest total amount of capital. Since 2006, over 100 companies have listed on ASSOB, and it is thus one of only a few platforms that currently possess sufficient data for a statistically significant analysis of equity crowdfunding offerings. Moreover, ASSOB operates in a legal environment that permits equity crowdfunding. We can view a study on ASSOB as a forward-looking illustration of how equity crowdfunding may ultimately work in other regions (such as the U.S.) in the near future.

\section{A. The ASSOB Investment Process}

ASSOB allows investors to browse small equity offerings of start-ups and to buy shares in these ventures. During registration, potential investors are required to provide certain personal information, including how much they expect to invest, and must confirm awareness of the potential risks involved in capital investments. Once registered, investors can peruse the general information on the offerings on what is called the "Primary Board". This includes company name, listing code, security type (e.g., ordinary shares), industry (e.g., “technology”), status of the capital-raising (e.g., “open”), total funding sought, minimum parcel size, and allocation status. If there is interest in a specific offering, the investor can then access a detailed offering overview (see Appendix C, “ASSOB Screenshots”). Table I summarizes the seven main sections in the overview.

If the investor wishes to proceed, the next step is to download detailed offering documents. The offering documents are prepared by the entrepreneurs in cooperation with "sponsors," typically professional business advisors such as accountants, corporate advisors, business 
consultants, finance brokers, or lawyers. Although offering documents are prepared individually for each entrepreneur, all follow a similar structure: 1) key investment highlights, 2) milestones achieved to date, 3) letter from the managing director, 4) business model, 5) market analysis, 6) financial projections, 7) purpose of the capital-raising, 8) offering details, 9) ownership structure, and 10) descriptions of the management team and external board members.

Based on this information, an investor can then apply for shares. A $10 \%$ security deposit is required at the time of application, with the remaining $90 \%$ due when the equity offering becomes effective, which occurs when the minimum number of shares has been sold. If a minimum number is not sold within the prespecified time frame, the equity offering does not become effective and investors are refunded their $10 \%$ deposits. The minimum number of shares is set individually for each start-up, and can differ significantly from the total funding amount requested.

- Table I about here -

\section{B. Dataset Construction}

Our sample consists of 104 equity crowdfunding offerings published on ASSOB between October 2006 and October 2011. All of these offerings were either listed for approximately one year - the most common offering period on ASSOB — or fully funded beforehand. To the best of our knowledge, this unique sample is the most comprehensive of equity crowdfunding offerings collected so far.

ASSOB provided a list of all 161 offerings for which they had basic information available in their database. 142 offerings had both basic information and offering documents available. Further matching with investor data reduced our sample to 104. According to ASSOB, when it first launched, it did not automatically store offering information, which explains the discrepancy between available listings and the number of total listings published on the site 
since 2006 (see Table II for summary statistics). However, all offerings were displayed in the same manner on ASSOB's offering overview site, and all follow the general structure described above, which ensures comparability.

For our matched sample of 104 offerings, we collected six types of data: 1) basic information for potential investors, 2) financial statement, 3) external certification, 4) board experience, 5) investment history, and 6) information on the speed of investment. The descriptive statistics for all variables are in Table III (note that the variable names used in the empirical analyses are in italics in parentheses after the descriptions).

- Tables II and III about here-

\section{Basic Information for Potential Investors}

The basic information includes the offering information from the Primary Board and the detailed company overview (see again Table I). ASSOB makes no changes to the entrepreneur's self-reported data except for the industry category, where it mandates that one of eight industry descriptions be applied to each start-up. We use this category as a control variable for industry fixed effects. Furthermore, we use the date on which the offering documents were placed on ASSOB to control for year fixed effects. Information on start-up location (headquarter) is used to control for the fact that projects in major cities may be perceived as more attractive than those in more rural areas, via the variable big city fixed effects.

\section{Capital Market Roadmap}

We also obtained information from start-up founders about how they typically structure the funding process. We collected three types of information: 1) most likely exit channel: IPO (most likely exit-IPO), trade sale (most likely exit-trade sale), or LBO, reverse takeover, and 
other (most likely exit-other), 2) number of planned years to exit (years to planned exit), and 3) target amount (target funding). All information comes from the original offering documents.

\section{External Certification}

External certification for potential investors includes any information on patents, government grants, or awards included in the offering documents. All offering documents include a subsection that lists the start-up’s intangible assets, and most mention registered trademarks. Only a small percentage of start-ups list registered or pending patents, so we can distinguish between start-ups that list patent ownership in their offering documents and those that do not (granted patent). Furthermore, some start-ups list government loans (government grant) or awards (award). All other information was obtained from the original offering documents, and all variables are designed as dummy variables.

\section{Board Experience}

We obtained management team information, such as composition and qualifications, from the offering documents. Every offering document includes short biographies of executive directors, non-executive directors, and, if applicable, key employees. We created a list of all 376 directors (board members) from the 104 offering documents, and noted for each the director type (e.g., executive versus non-executive), and whether the director holds an MBA. We also calculated the total number of board members (\# board), percentage of non-executive directors on a company's board (\% non-executive board), number of staff employed (\# staff), percentage of directors holding an MBA (\% board $M B A)$, and number of years a start-up has been in business at the time of offering (years in business). All came from the detailed company overview page. 
Risk Level

Information on the potential risk level also comes from the offering documents. Financial forecasts for potential investors generally refer to sales, EBITDA, EBIT, and net earnings forecasts. But there is no standard way to present forecasting information on ASSOB, and start-ups can decide whether to provide forecasts, and which items to provide if they do. Startups that opt not to provide a forecast can integrate a standard legal disclaimer ${ }^{9}$ into their documents. This generally states that the directors believe there is no reasonable basis to forecast future earnings because the operations of the company are inherently uncertain.

We calculate two dummy variables from the disclosure policy: 1) a cross term indicating that the start-up has not provided a financial forecast but has included a disclaimer (disclaimer $x$ no financial forecast), and 2) a cross term indicating that the start-up has not provided a financial forecast or a disclaimer (no disclaimer $x$ no financial forecast). Furthermore, we calculate the percentage offered to investors (equity offering) and the number of intended financing rounds (intended number of rounds).

\section{Investment History}

Investment history describes individual investors’ prior investments on ASSOB. For each investment, ASSOB provided information on total number of shares purchased, as well as total amount of AUD invested (funding amount) and by how many investors (number of investors). Of the 104 start-ups, 67 received funding, although not necessarily full funding. The total amount of funding received by all start-ups combined was AUD 33.1 million, which

\footnotetext{
${ }^{9}$ The disclaimer reads: "The Directors have considered the matters set out in ASIC Regulatory Guide 130: Prospective Financial Information, and believe that they do not have a reasonable basis to forecast future earnings because the operations of the Company are inherently uncertain. Any forecast or projection would necessarily contain such a broad range of potential outcomes and possibilities that it would be unreliable and, for that reason, the Directors have decided not to include any financial projections or forecasts.”
} 
is an average of AUD 490,000 for each start-up that received funding. The maximum funding amount was AUD 3.5 million (see Table III).

\section{Speed of Investment}

As mentioned above in section II, founders can choose the number of financing rounds they engage in (up to three). However, we collect detailed information only on the first round, because the number of observations for the second and third rounds is too low to be meaningful. We control for the number of planned rounds (intended number of rounds). We are left in the first round with ninety-two start-ups, of which nineteen successfully completed their first financing round, i.e., all shares offered were sold. Given a successful completion, we can calculate the number of days from the opening day for investors until the day the targeted amount was raised (duration of first financing round). Projects that were only partially funded or not funded at all are delisted by ASSOB after one year. Furthermore, we obtain information on parcel size in the first financing round (parcel size), and the demanded share price (share price). 


\section{Theoretical Background and Empirical Analysis: Signaling in Equity Crowdfunding}

In this section, we develop propositions about signaling in an equity crowdfunding context, and we analyze the extent to which these propositions are supported by the empirical data available from ASSOB. Section A analyzes which signals lead to higher numbers of investors and larger funding amounts; section B describes the determinants of the speed of investing, which we consider another dimension of funding success.

\section{A. What Drives the Funding Success of Start-Up Proposals?}

Similarly to VC financing, with start-ups, there is a concern about information asymmetries between investors and entrepreneurs (Connelly et al., 2011). Naturally, the entrepreneur is assumed to have better knowledge about the true quality of the start-up than the potential investor (see, for example, Michael, 2009; Backes-Gellner and Werner, 2007; and Busenitz, Fiet and Moesel, 2005). This is even more pronounced in an equity crowdfunding context, however, because small investors are less likely to have experience evaluating investment opportunities. In the extreme case, one could argue that potential investors may not have the ability to determine anything concrete about the true quality of a start-up, and consequently even potentially high-performing start-ups may not receive funding.

This illustrates the problem of adverse selection in entrepreneurial finance that is mentioned by Leland and Pyle (1977), who state that "where substantial information asymmetries exist and where the supply of poor projects is large relative to the supply of good projects, venture capital markets may fail to exist” (p. 371). For start-ups on crowdfunding platforms, these information asymmetries are comparably higher, because gathering 
information, monitoring progress, and providing input are particularly important for earlystage investors, but the costs of these activities are sensitive to distance (see Agrawal, Catalini, and Goldfarb, 2011).

As we noted in the previous section, start-ups have been able to raise substantial amounts of funding through platforms such as ASSOB, SeedUps, or Crowdcube. Therefore, small investors have seemingly been able to infer the quality of start-ups by interpreting the information provided on the platform. In this sense, small investors regard at least some of the information as signals of quality, because not all start-ups obtain financing. These signals could derive, for example, from the positive, unobservable qualities of the entrepreneurs (Spence, 1973, 2002; Busenitz, Fiet and Moesel, 2005). As Stuart, Hoang, and Hybels (1999, p. 317) state, “[B]ecause the quality of young companies often cannot be observed directly, evaluators must appraise the company based on observable attributes that are thought to covary with its underlying but unknown quality. Resource holders therefore assess value by estimating the conditional probability that a firm will succeed, given a set of observable characteristics of the organization.”

For funders, an unobservable quality may be the ability of a start-up to earn certain cash flows in the future (see Ross, 1978). If we assume that funders and entrepreneurs act rationally, the latter will signal to the former (see Michael, 2009). In this context, Grossman (1981) and Milgrom (1981) show theoretically that funders will infer from entrepreneurs who fail to provide information that their start-ups are of below-average quality. This creates a strong incentive, however, to provide information, which can lead to an "unraveling effect," where all firms signal in equilibrium. ${ }^{10}$

\footnotetext{
${ }^{10}$ Neither paper specifically addresses start-ups, however. Instead, both papers develop theoretical models and show that the competitive market provides adequate incentives for sellers to reveal information to buyers (Michael, 2009). Grossman (1981) analyses the informational role of warranties and private disclosures about product quality. Milgrom (1981) develops an abstract model.
} 
But not all the information provided by start-ups will ultimately be effective signals to help overcome the problem of information asymmetry. Effective signals share two characteristics: observability and signal cost. Observability is the extent to which the signal is noticed and understood by investors; signal cost must be structured so that dishonest signals are not rewarded, and so the cost of producing the signal doesn't outweigh its benefits (see, e.g., Connelly et al., 2011).

In our context, investors will likely be able to use the information provided by entrepreneurs in the offering documents (e.g., the capital market roadmap, external certification, board experience, and risk level) as signals (see section II). In our analysis, we use zero-inflated negative binomial regressions to investigate which factors influence the number of funders. We choose this method to control for factors that potentially affect whether a project will get any funding. In particular, we control for the possibility that projects initiated during the earlier days of the platform's existence had a lower probability of attracting investors because crowdfunding was not yet an established investment channel. Thus, projects that went unfunded in the past on ASSOB may not have had undesirable characteristics, but there may have been greater investor inexperience with this type of fundraising platform. Moreover, in addition to the number of investors, we use OLS regressions to analyze which factors drive absolute funding amount.

\section{Capital Market Roadmap}

We find that the suggested exit channel in the offering document is likely to influence funding success. In the past, IPOs and trade sales realized the highest returns for investors, compared to other exit forms, but they also tend to be riskier in terms of realization (see, for example, Black and Gilson, 1998; Nahata, 2008; and Cumming and Johan, 2009). Timing is 
particularly important for IPOs, because IPO markets tend to dry up during, for example, financial crises, and this can create substantial timing risk for investors.

Using the IPO exit channel as our reference category, we find that it attracts significantly more investors than the trade sales exit channel. Both channels attract significantly more investors than start-ups that use other exit channels, or those that do not indicate exit strategy (see rows 2 and 3 in Table IV). These results provide support for risk-sharing or "syndicating” investor behavior, as posited by Wilson (1968).

Regarding the number of planned years to exit, we find no empirical evidence that this signal influences the number of small investors for young start-ups, although some theories do predict such an influence. ${ }^{11}$ On the one hand, liquidity preference theory argues for short durations, because they do not tie up capital as long; on the other hand, a low number of years to planned exit could be interpreted as a signal of relatively high confidence. Presumably, entrepreneurs who plan to exit within one year have more straightforward roadmaps than those who plan to exit in seven years. Given such evidence, it seems investors do not value the number of planned years to exit as a meaningful signal. It may also be that grandstanding and liquidity effects are balancing out the fact that it generally requires a certain amount of lead time to build a sustainable company.

To explore whether investors prefer small or large investment opportunities in equity crowdfunding, we also control for targeted funding amount. We find that neither the number of investors attracted to a project nor total funding amount is significantly influenced by project size, however (compare row 5 in Tables IV and V).

\footnotetext{
${ }^{11}$ Gompers (1996), for example, notes that founders of young start-ups, similarly to new venture capital firms, may have an incentive to grandstand, and they may be more focused on taking their companies public than on maximizing company value.
} 


\section{External Certification}

Davila, Foster, and Gupta (2003) argue that entrepreneurs can also signal unobservable characteristics of their start-ups by affiliating themselves with third parties such as venture capitalists. Likewise, Gulati and Higgins (2003) and Megginson and Weiss (1991) show that ties to prominent venture capitalists or investment banks are effective signals in an IPO context, and can also act as forms of external certification. Hsu (2004) shows that entrepreneurs are therefore willing to pay for venture capital affiliation, because they believe venture capitalists can beget a reputation effect that will facilitate growth (Davila, Foster and Gupta, 2003). Potential investors or employees can also observe which start-ups receive venture capital funding. Moreover, undergoing a lengthy due diligence process can be costly.

In an equity crowdfunding context, however, where founders seek seed financing, start-ups are generally not affiliated with venture capitalists prior to the offering. Following a similar rationale, we argue that patents, grants, and awards may meet Spence's (1973) original conceptualization of a signal, and provide investors with external (but costly for founders) quality assessments (see Hsu and Ziedonis, 2007). Patent registration can be expensive, due to registration fees, legal advice etc., but a start-up’s ownership of a registered patent at the time of offering shows that an entrepreneur has already incurred the costs. Moreover, patent ownership can protect against the risk of future market entrants, so it could be interpreted as a signal of a company's strength and quality.

Therefore, third-party endorsements are likely to have a positive effect on attractiveness to investors. Surprisingly, we do not find that any of these signals results in a higher number of funders or in a higher funding amount, though (see rows 6-8, Tables IV and V). We note that patents likewise have been shown to have no signaling value for other types of pre-venture capital financing markets (Conti et al., 2010). One interpretation is that such projects are at too early a stage for patents to be reasonably expected, and that if the firm has patents and 
seeks crowdfunding then it might signal the firm had a lack of success with other types of investors such as venture capitalists.

\section{Board Experience}

In addition to external certification, the educational background of entrepreneurs can also be viewed as a useful signal of otherwise unobservable entrepreneurial productivity. BackesGellner and Werner (2007) examine this angle empirically, and find that educational signals are often viewed as signals of innovation. Similarly, Levie and Gimmon (2008) argue that educational degrees are an effective signal for first-time high-technology venture founders. However, neither set of authors examines the effectiveness of educational signals for entrepreneurs in pure start-ups.

As a signal of the unobservable management ability of an entrepreneur, we choose an MBA degree as a proxy for education. It is observable to (small) investors (e.g., through biographies in the offering documents), and is costly to acquire (both in tuition and in time). Furthermore, it can only be acquired by qualified candidates, and MBA graduates are often part of exclusive networks. Given that most MBA programs require applicants to have work experience, an MBA degree also denotes some professional experience and maturity. Thus, we expect that MBA graduates will tend to be more effective in attracting financing than others, due to, e.g., their broader network.

In line with previous arguments, we find statistically significant empirical evidence that the percentage of MBA graduates among executive board members of a founding team increases the number of investors. More precisely, a one-percentage point increase in board members who hold MBAs increases the expected number of investors by a factor of 1.018, holding all 
other variables constant (row 11, Table IV). ${ }^{12}$ In contrast, we find no impact on total funding amount (row 11, Table V).

A further signal for investors could be the number of staff and board members. We note that, on the one hand, a high number of staff suggests either profitability (the entrepreneur is able to pay employees from the company's revenues), or a willingness to invest personal wealth (i.e., paying staff out of one's own pocket), which is a costly signal. Common sense suggests the latter is more likely for a start-up prior to its seed financing round. A high number of staff also suggests that an entrepreneur has been able to convince employees of the firm's potential.

On the other hand, however, a higher number of board members signals more highly incentivized people within generally varied backgrounds striving for the start-up’s success (a qualitative assessment that can be made by reading the short bios in the offering documents). Furthermore, board members have usually been granted external options, and therefore face opportunity costs.

The endorsement of non-executive directors could also be argued to have a signaling effect. Non-executive directors are often respected industry veterans who act as mentors to start-ups. They can add to the start-up's legitimacy, and can introduce entrepreneurs to potential new stakeholders (such as clients). Furthermore, experienced managers usually have only a limited amount of time to devote to such efforts. Thus, the support of a non-executive director may be viewed as a signal that the start-up has successfully undergone some kind of due diligence process.

We expect that more staff and more board members, as well as a higher share of nonexecutive directors, will positively impact funding success. And in addition to the positive effect of board members who hold MBA degrees, we find that a higher number of board

\footnotetext{
12 The expected number of investors changes by the factor of exp(coefficient) for each unit change in the respective predictor, holding all other variables constant. In this case, the expected number of funders increases by a factor of $\exp (0.018)=1.018163$.
} 
members has a positive and statistically significant impact on funding success for both higher expected number of investors, and for higher funding amount. As Table IV shows, an additional member on the board increases the expected number of investors by a factor of $1.433(\exp (.360))$ (see row 9, Table IV), and increases expected total funding amount by 126,000 AUD (0.126*1,000,000 AUD) (see row 9, Table V). However, we find no statistically significant impact on funding success for the number of staff or non-executive directors (compare rows 10 and 12 in Tables IV and V).

A complementary signal to small investors could be the mix of entrepreneurial experience and financial commitment (Prasad, Bruton and Vozikis, 2000; Conti, Thursby and Rothaermel, 2010). Prasad, Bruton, and Vozikis (2000) build on Leland and Pyle (1977), and argue that the percentage of personal wealth an entrepreneur invests in a company should be as effective a positive signal as experience. The percentage of personal wealth invested in a company and the experience of an entrepreneur are not obvious to investors on equity crowdfunding platforms. But there are different possible proxies. For example, small investors can interpret the number of years that a start-up has been in business as an indicator of how much time and money an entrepreneur has devoted to building the company and gained in experience. However, we find no statistically significant impact from this variable on the number of investors or on realized funding amount (compare row 13 in Tables IV and $\mathrm{V})$.

\section{Risk Level}

The riskiness of the proposed projects is a highly valuable signal for investors. In this sense, Leland and Pyle (1977) argue that entrepreneurs can signal unobservable characteristics of their start-up by the amount of equity they retain after an offering. The rationale is that it is costly for entrepreneurs to retain ownership interests, and so they will 
only retain a "substantial" stake if they expect future cash flows to be high relative to current firm value.

Furthermore, a substantial stake in the start-up can help better align the interests of funders and founders. Therefore, we expect a higher amount of offered equity to negatively affect funding success, and we find a negative and significant influence with respect to the expected number of investors (row 14, Table IV). We find that a one-percentage point increase in equity offered decreases the expected number of investors by a factor of 0.982161 (exp (0.018)). This finding is in line with Downes and Henkel (1982), who provide empirical evidence that entrepreneurial ownership is an effective signal in an IPO context.

Note that earnings forecasts are optional in Australia. We thus posit that they are credible signals that can proxy for the risk level of a start-up on ASSOB (see Michael, 2009, for a related study on franchise entrepreneurs). Australian law requires a "reasonable basis to forecast future earnings.” ${ }^{13}$ If a reasonable basis for forecasts exists, it is usually explicitly stated in the offering document. Earnings statements—such as EBIT or sales estimates_are therefore clearly observable to investors. We could also argue that the risk of legal prosecution makes such forecasts relatively expensive, which further strengthens the credibility of the signal.

Moreover, if entrepreneurs do not have a reasonable basis for forecasts, they can choose not to report financial predictions. But they still have the opportunity to include a disclaimer in the offering document that will describe the risks in more detail and explain the lack of forecasts. This provides a more precise overview of the risks, and it can help lessen asymmetric information because investors will have a better basis on which to form earnings expectations (Epstein and Schneider, 2008).

We posit that including a disclaimer will help increase total funding amount, because it helps clarify expectations about companies' future prospects. On the other hand, offering no

\footnotetext{
${ }^{13}$ ASIC Regulatory Guide 170: Prospective Financial Information.
} 
disclaimer and no financial forecasts increases the risk of ambiguous information. In those cases, we find a statistically significant 206,000 AUD decrease in total funding amount compared to start-ups that include a financial forecast (see row 16, Table V).

Another indication of the riskiness of a project is the number of intended financing rounds, which can vary from one to three and is known by investors. Founders who choose to engage in only one financing round may be forgoing two advantages: 1) the benefits of the announcement that they have successfully completed their first round, which is viewed positively by investors, and 2) an equal or (in most cases) higher share price in further rounds. These advantages can create a kind of group dynamic for interested investors who see that only a few parcels are left, which can increase the likelihood of investing. We do not find a significant influence on expected number of investors or on total funding amount, but we do find an expected positive effect on speed of investment.

- Table IV and 5 about here -

\section{B. What Drives the Speed of Investment?}

Since Penrose's (1959) original "theory of the growth of the firm," where managerial resources were found to play a pivotal role, several factors have been suggested that can affect growth. Some (such as environmental carrying capacity or market forces) are external to the organization. Others (capabilities, culture, strategy etc.) are internal, and have been addressed from the resource-based view of the firm. Within the field of entrepreneurship, previous research has examined additional factors, and found that funding events are relevant to the evolution of growth.

Along these lines, we argue that one of the success determinants for founders in the startup phase is to receive the required financing in a timely fashion without disrupting the growth path. This is especially important for "high-growth" start-ups, because they often need to rely 
on timely execution to take advantage of early-mover advantages; delayed execution may thus have significantly negative consequences for their success.

Given that we regard speed of investment as an important factor in start-up success, we need to determine which factors explain the duration of the first financing round. On the ASSOB platform, management has several degrees of freedom within which to structure their financing process: target amount, number of financing rounds, parcel size, and share price. They must first define their target amount and denote the number of rounds (one to three) they wish to engage in (see Appendix C, screenshot 1, for two examples: Biodental Remein Ltd., which engaged in three rounds, and Aware Environment, which engaged in two).

Next, they define parcel size for each round, which means that only whole number parcel shares may be purchased by investors within the total amount available per round. To find out whether parcels are still available, on the ASSOB platform, one must check the status of the “red squares” (see again Appendix C, screenshot 1). Each red square represents a completed capital-raising parcel (for example, note that two parcels were raised by Female Friendly Limited). Grey squares represent available parcels. At the time of the screen shot, Biodental Remein Ltd. had completely filled the first two rows of red squares, which means it had successfully completed two rounds of capital-raising via ASSOB, and the remaining third round was still open. The status of individual ASSOB offerings is continually updated, so there is always complete transparency about an offering's status. And, as we mentioned earlier, start-ups that do not reach their minimum threshold for investment after one year are delisted. The last regulatory item for founders is the average share price in each financing round (see Appendix C, screenshot 2).

To further explore the speed of investment, we use survival analyses. More specifically, we use exponential hazard models ${ }^{14}$ to identify which factors reduce the time to completion of the

\footnotetext{
${ }^{14}$ We use the Akaike Information Criterion (AIC) to select the best-fitting model, which in our case is the exponential specification (Cleves, Gould and Gutierrez, 2008).
} 
first financing round. Analogously to our previous analyses, we again find that one of the most important factors in shorter financing durations is a start-up's risk level. We find that higher percentages of offered equity and less information provided by founders are associated with later expected completions of the first financing round (rows 14 and 16, Table VI).

Interestingly, we noted in the previous subsection that the number of years a start-up has been in business does not significantly influence the expected number of investors or total funding amount. But we find here that more mature start-ups have a higher likelihood of closing their first financing round earlier (row 13, Table VI). Moreover, a higher number of intended rounds leads to faster completion of the first financing round (row 17, Table VI).

\section{- Table VI about here-}

In summary, we find strong empirical evidence that signaling plays an important role for investors, especially with respect to potential risk factors, share of equity offered, and board structure and size. The relationships among the aforementioned factors and the number of investors, total funding amount, and speed of the first financing round become apparent on an aggregate project level, but further analysis would be needed to understand the other side of the equation, i.e., individual investors' decision-making processes. In particular, we are interested in determining which projects will be perceived as suitable investment alternatives from an individual investor's viewpoint.

Within this context, we believe that obtaining information on 1) the length of time investors take to screen the market and thus the platform before they invest in a project, and 2) whether the final choice set is restricted to a specific industry, time period, investment pattern, or region would further contribute to our understanding of crowdfunding dynamics. While these questions are clearly beyond the scope of this paper, our initial inspection of the available ASSOB data for the 104 projects shows that approximately 53\% of investors invest in projects that are headquartered in their state of residence. This suggests that geographic distance between investors and entrepreneurs remains an important factor in investor 
decision-making. Early-stage projects are particularly susceptible, because long distances can create barriers to acquiring information and can increase monitoring costs. Therefore, further analyses are necessary to understand whether crowdfunding platforms can indeed eliminate these distance-related economic frictions (see Agrawal, Catalini and Goldfarb, 2011).

\section{Conclusion}

This paper is the first to conduct an empirical examination of the effectiveness of different types of signals used by start-ups to induce small investors to commit financial resources in an equity crowdfunding context. The data highlight the importance of financial roadmaps (such as preplanned IPO or acquisition exit strategies) and risk factors (such as amount of equity offered and whether financial forecasts are provided), as well as board experience, measured by education level (e.g., percentage with MBA degrees), and number of board members. We found that external certification (including patents and government grants), in contrast, had little or no significant impact on success.

The findings have interesting implications for both practitioners and policymakers. For entrepreneurs that use crowdfunding, the data suggest that presenting financial projections and roadmaps to potential investors can increase the likelihood of success. Moreover, internal governance, such as, e.g., proper board structure and more highly qualified board members, can enhance the likelihood of attracting investors and the speed of capital-raising.

With respect to policy implications, our data also highlight the fact that the crowdfunding market operates in a largely rational manner, even among retail investors who are arguably less sophisticated. Crowdfunding investors seem to pay a great deal of attention to the financial and governance material that firms provide. However, at this point, the industry is still in its infancy, and thus our data do not enable us to make a meaningful evaluation of firm outcomes yet. We hope such issues will be explored further as more data become available. 


\section{References}

Agrawal, A., Catalini, C., and Goldfarb, A. (2011): The Geography of Crowdfunding, Available at SSRN: http://ssrn.com/abstract $=1692661$.

Backes-Gellner, U., and Werner, A. (2007): Entrepreneurial Signaling via Education: A Success Factor in Innovative Start-Ups, Small Business Economics 29, 173-190.

Belleflamme, P., Lambert, T., and Schwienbacher, A. (2010): Crowdfunding: An Industrial Organization, Working Paper.

Belleflamme, P., Lambert, T., and Schwienbacher, A. (2012): Crowdfunding: Tapping the Right Crowd, Available at SSRN: http://ssrn.com/abstract $=1578175$.

Black, B.S., and Gilson, R.J. (1998): Venture Capital and the Structure of Capital Markets: Banks versus Stock Markets, Journal of Financial Economics 47, 243-277.

Bradford, S.C. (2012): Crowdfunding and the Federal Securities Laws, Columbia Business Law Review, 2001(1), 3-148.

Burtch, G., Ghose, A., and Wattal, S. (2012): An Empirical Examination of the Antecedents and Consequences of Investment Patterns in Crowd-Funded Markets, Working Paper.

Busenitz, L.W., Fiet, J.O., and Moesel, D. (2005): Signaling in Venture Capitalists-New Venture Team Funding Decisions: Does It Indicate Long-Term Venture Outcomes? Entrepreneurship Theory and Practice 29, 1-12.

Cleves, M.A., Gould, W.W., and Gutierrez, R.G. (2008): An Introduction to Survival Analysis using STATA. STATA Press Publication, Texas.

Cole, R.A., and Sokolyk, T. (2012): How Do Start-Up Firms Finance Their Assets? Evidence from the Kauffman Firm Surveys, Working Paper, Depaul University.

Connelly, B.L., Certo, S.T., Ireland, R.D., and Reutzel, C.R. (2011): Signaling Theory: A Review and Assessment, Journal of Management 37, 39-67.

Conti, A., Thursby, M., and Rothaermel, F.T. (2010): Show Me What You Have: Signaling, Angel and VC Investments in Technology Startups, Journal of Economics and Management Strategy, forthcoming.

Cosh, A., Cumming, D.J., and Hughes, A. (2009): Outside Entrepreneurial Capital, Economic Journal 119, 1494-1533.

Crowdfunding Industry Report (2012): Crowdfunding Industry Report: Market Trends, Composition and Crowdfunding Platforms: Crowdsourcing, LLC.

Cumming, D.J., and Johan, S.A. (2009): Venture Capital and Private Equity Contracting: An International Perspective, Elsevier Science Academic Press.

Davila, A., Foster, G., and Gupta, M. (2003): Venture Capital Financing and the Growth of Startup Firms, Journal of Business Venturing, 18, 689-708. 
Downes, D.H., and Henkel, R. (1982): Signaling and the Valuation of Unseasoned New Issues, Journal of Finance 37, 1-10.

The Economist (2012): Uncuffing Capitalism: A Welcome Attempt to Restore the Appeal of Initial Public Offerings in America, http://www.economist.com/node/21551481.

Empson, R. (2012): With JOBS Act Becoming Law, Crowdfunding Platforms Look to Create Self-Regulatory Body, http://techcrunch.com/2012/04/05/with-jobs-act-becoming-lawcrowdfunding-platforms-look-to-create-self-regulatory-body.

Epstein, L.G., and Schneider, M. (2008): Ambiguity, Information Quality, and Asset Pricing, Journal of Finance 63, 197-228.

Forbes Magazine (2012): An Interview with Carl Esposti, Crowdfunding Industry Research, http://www.forbes.com/sites/alanhall/2012/05/14/an-interview-with-carl-esposticrowdfunding-industry-research.

Freear, J., Sohl, J.E., and Wetzel Jr., W E. (1994): Angels and Non-Angels: Are there Differences? Journal of Business Venturing 9, 109-123.

Goldfarb, B., Kirsch, D., and Miller, D. (2007) Was there too Little Entry in the Dot Com Era? Journal of Financial Economics 86, 100-144.

Gompers, P.A. (1996): Grandstanding in the Venture Capital Industry, Journal of Financial Economics 42, 133-156.

Griffin, Z.J. (2012): Crowdfunding: Fleecing the American Masses, Working Paper.

Grossman, S.J. (1981): The Informational Role of Warranties and Private Disclosure about Product Quality, Journal of Law and Economics 24, 461-483.

Gulati, R., and Higgins, M.C. (2003): Which Ties Matter When? The Contingent Effects of Interorganizational Partnerships on IPO Success, Strategic Management Journal 24, 127144.

Hemer, J. (2011): A Snapshot on Crowdfunding, Working Paper.

Hsu, D.H. (2004): What Do Entrepreneurs Pay for Venture Capital Affiliation? Journal of Finance, 59, 1805-1844.

Hsu, D.H., and Ziedonis, R.H. (2007): Patents as Quality Signals for Entrepreneurial Ventures, Working Paper.

Kutner, M. H., Nachtsheim, C. J., Neter, J., and Li, W. (2005): Applied Linear Statistical Models, $5^{\text {th }}$ edition. New York: McGraw-Hill.

Leland, H.E., and Pyle, D.H. (1977): Informational Asymmetries, Financial Structure, and Financial Intermediation, Journal of Finance 32, 371-387.

Levie, J., and Gimmon, E. (2008): Mixed Signals: Why Investors May Misjudge First Time High Technology Venture Founders, Venture Capital 10, 233-256. 
Lin, M., Prabhala, N., and Viswanathan, S. (2009): Social networks as signaling mechanism:

Evidence from online peer-to-peer lending, Working Paper.

Malmendier, U., and Shanthikumar, D. (2007): Are Small Investors Naive about Incentives? Journal of Financial Economics 85, 457-489.

Megginson, W., and Weiss, K. (1991): Venture Capital Certification in Initial Public Offerings, Journal of Finance 46, 879-903.

Michael, S.C. (2009): Entrepreneurial Signaling to Attract Resources: The Case of Franchising, Managerial and Decision Economics 30, 405-422.

Milgrom, P.R. (1981): Good News and Bad News: Representation Theorems and Applications, Bell Journal of Economics 12, 380-391.

Mollick, E.R. (2012): The Dynamics of Crowdfunding: Determinants of Success and Failure, Available at SSRN: http://ssrn.com/abstract $=2088298$.

Nahata, R. (2008): Venture Capital Reputation and Investment Performance, Journal of Financial Economics 90, 127-151.

Penrose, E.T. (1959): The Theory of the Growth of the Firm. New York, John Wiley.

Prasad, D., Bruton, G.D., and Vozikis, G. (2000): Signaling Value to Business Angels: The Proportion of the Entrepreneur's Net Worth Invested in a New Venture as a Decision Signal, Venture Capital 2, 167-182.

Robb, A., and Robinson, D. (2012): The Capital Structure Decisions of Startup Firms, Review of Financial Studies, forthcoming.

Ross, S.A. (1978): Some Notes on Financial Incentive-Signalling Models, Activity Choice and Risk Preferences, Journal of Finance, 33, 777-792.

Schwienbacher, A., and B. Larralde (2010): Crowdfunding of Small Entrepreneurial Ventures, Working Paper.

Spence, M. (1973): Job Market Signaling. Quarterly Journal of Economics 87, 355-374.

Spence, M. (2002): Signaling in Retrospect and the Informational Structure of Markets, American Economic Review 92, 434-459.

Stuart, T.E., Hoang, H., and Hybels R. (1999): Interorganizational Endorsements and the Performance of Entrepreneurial Ventures, Administrative Science Quarterly 44, 315-349.

Wilson, R. (1968): The Theory of Syndicates, Econometrica 36, 119-132. 
Figure 1: Complexity and Uncertainty of Crowdfunding Business Models

This figure illustrates the differing levels of complexity and uncertainty over donations crowdfunding, rewardbased crowdfunding, lending crowdfunding, and equity crowdfunding. Equity crowdfunding is the most complex from both a legal standpoint and with respect to information asymmetries (adapted from Hemer, 2011).

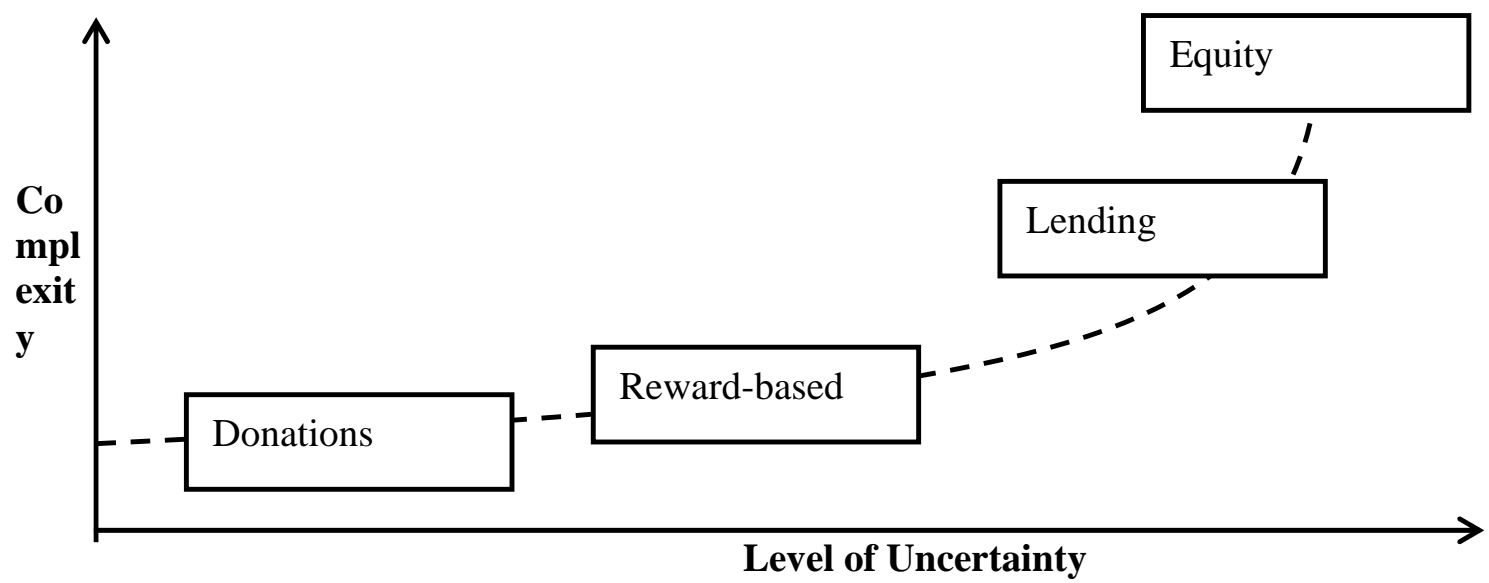

Figure 2: Number of Crowdfunding Platforms by Type, as of April 2012

This figure shows the percentage of equity crowdfunding platforms among all types of crowdfunding platforms. The total is 452 . Equity crowdfunding platforms are differentiated by platforms that finance businesses (e.g., start-ups) and other projects.

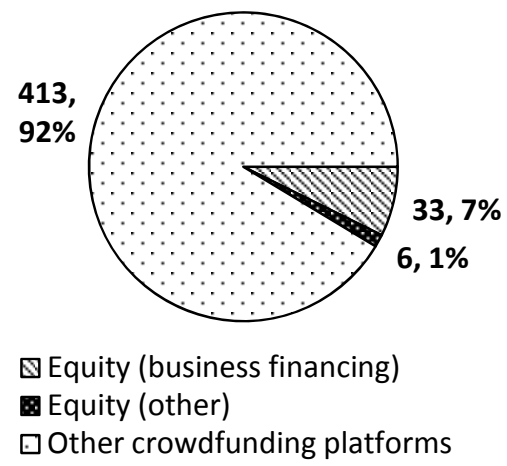


Figure 3: Total Volume Raised Through Crowdfunding Platforms

This figure shows the growth of crowdfunding volume between 2009 and 2011 in U.S.\$ millions. The equity crowdfunding numbers are at the top of the bars.

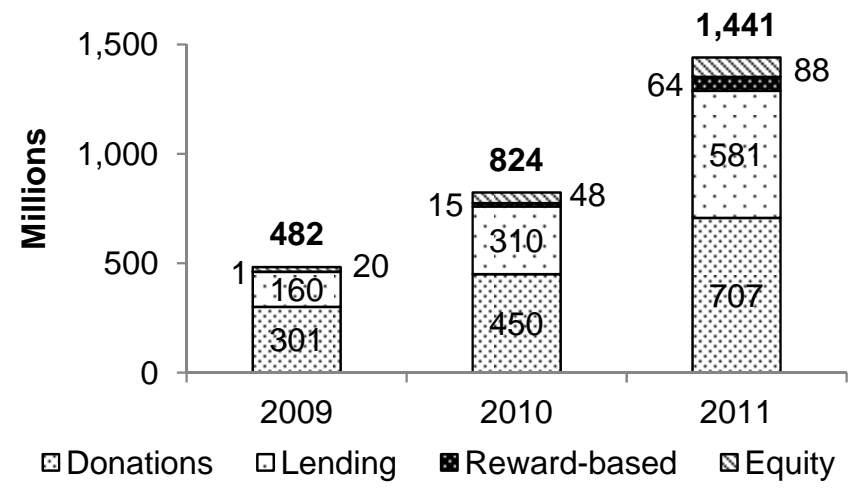


Table I: Information in "Detailed Company Overviews"

This table shows the different sections of the detailed company overview provided by each entrepreneur on ASSOB. This information is displayed when a potential investor clicks on the company on the offering overview site.

\begin{tabular}{|c|c|}
\hline Section & Description \\
\hline About & $\begin{array}{l}\text { - Investment summary and company details, including number of current investors, company } \\
\text { location, years in business, industry category, years to planned exit, most likely exit } \\
\text { strategy (IPO, trade sale, etc.), current fundraising status, allocation status, and link to } \\
\text { company homepage } \\
\text { - Link to download key investment documents }\end{array}$ \\
\hline Bid/Sell & - Investors can make a bid for company shares \\
\hline Contact & - Investors can send an email to aspiring entrepreneurs \\
\hline Sales Tracker & $\begin{array}{l}\text { - Overview of share purchases by other small investors, including information on volume, } \\
\text { price, and value }\end{array}$ \\
\hline People & - Overview of other small investors who follow a certain company \\
\hline Blog & - Company blog, integrated into the ASSOB site \\
\hline Q\&A & - Public Q\&A section \\
\hline
\end{tabular}

Table II: Crowdfunding on ASSOB - Summary Statistics

This table gives an overview of the crowdfunding start-up sizes funded on the ASSOB platform in our sample and initiating date. Panel A includes only start-ups that actually received funding (67); volumes are in thousands AUD. Panel B provides an overview over time of the industries the start-up team focuses on. This includes all start-ups in our sample (104).

\section{$\underline{\text { Panel A }}$}

\begin{tabular}{|c|c|c|c|c|c|c|c|c|}
\hline & & 2006 & 2007 & 2008 & 2009 & 2010 & 2011 & Total \\
\hline \multicolumn{2}{|l|}{$\begin{array}{l}\text { Crowd } \\
\text { Fin. Volume }\end{array}$} & 3,540 AUD & 1,222 AUD & 6,708 AUD & 5,581 AUD & 11,864 AUD & 4,216 AUD & 33,131 AUD \\
\hline \multirow{5}{*}{$\begin{array}{l}\text { Crowd Fin. } \\
\text { Count } \\
\text { Crowd Fin. } \\
\text { Volume }\end{array}$} & & 1 & 3 & 15 & 12 & 26 & 10 & 67 \\
\hline & $<\$ 500,000$ & 0 AUD & 90 AUD & 2,345 AUD & 1,552 AUD & 4,621 AUD & 1,552 AUD & 10,159 AUD \\
\hline & $\begin{array}{l}\$ 500,000 \text { - } \\
\text { \$1million }\end{array}$ & 0 AUD & 1,132 AUD & 1,150 AUD & 1,615 AUD & 2,777 AUD & 1,564 AUD & 8,238 AUD \\
\hline & \$1 - \$2million & 0 AUD & 0 AUD & 1,200 AUD & 2,415 AUD & 4,466 AUD & 1,100 AUD & 9,180 AUD \\
\hline & $>\$ 2$ million & 3,540 AUD & 0 AUD & 2,014 AUD & 0 AUD & 0 AUD & 0 AUD & 5,554 AUD \\
\hline \multirow{4}{*}{$\begin{array}{l}\text { Crowd Fin. } \\
\text { Count }\end{array}$} & $<\$ 500,000$ & & 1 & 11 & 7 & 19 & 7 & 45 \\
\hline & $\begin{array}{l}\text { \$500,000 - } \\
\text { \$1 million }\end{array}$ & & 2 & 2 & 3 & 4 & 2 & 13 \\
\hline & $\$ 1$ - \$2 million & & & 1 & 2 & 3 & 1 & 7 \\
\hline & $>\$ 2$ million & 1 & & 1 & & & & 2 \\
\hline
\end{tabular}

\section{Panel B}

Industry

Agriculture

Mining

Construction

Technology /Manufacturing

Transport

Retail /Financial Services/Real Estate

Property

Professional Services

Sum

\begin{tabular}{ccccccc}
$\mathbf{2 0 0 6}$ & $\mathbf{2 0 0 7}$ & $\mathbf{2 0 0 8}$ & $\mathbf{2 0 0 9}$ & $\mathbf{2 0 1 0}$ & $\mathbf{2 0 1 1}$ & Total \\
0 & 0 & 0 & 0 & 0 & 0 & 0 \\
0 & 1 & 3 & 1 & 2 & 0 & 7 \\
0 & 0 & 1 & 1 & 1 & 0 & 3 \\
0 & 0 & 5 & 6 & 13 & 5 & 29 \\
0 & 0 & 1 & 4 & 3 & 1 & 9 \\
0 & 0 & 1 & 1 & 1 & 1 & 4 \\
0 & 0 & 4 & 1 & 2 & 3 & 10 \\
1 & 2 & 7 & 10 & 17 & 5 & 42 \\
\hline 1 & 3 & 22 & 24 & 39 & 15 & 104
\end{tabular}


Table III: Descriptive Statistics

This table shows the mean, standard deviation (std), minimum value (min), and maximum value (max) for all variables in Appendix A. The sample covers 104 crowdfunding start-ups.

\begin{tabular}{|c|c|c|c|c|c|}
\hline & $\begin{array}{c}\# \\
\text { Obser- } \\
\text { vation }\end{array}$ & Mean & Std & Min & Max \\
\hline \multicolumn{6}{|l|}{ Dependent Variables } \\
\hline Funding Amount & 104 & 318,568 AUD & 515148.7 & 0 AUD & 3,540,473 AUD \\
\hline $\begin{array}{l}\text { Number of Investors } \\
\text { (without Founders ) }\end{array}$ & $\begin{array}{c}104 \\
(104)\end{array}$ & $\begin{array}{c}7.52 \\
(7.09)\end{array}$ & $\begin{array}{l}12.05 \\
(9.58)\end{array}$ & $\begin{array}{c}0 \\
(0)\end{array}$ & $\begin{array}{c}88 \\
(57)\end{array}$ \\
\hline Duration of First Financing Round & 92 & 317.72 & 104.81 & 7 & 374 \\
\hline (if successfully funded) & 19 & 135.37 & 106.31 & 7 & 374 \\
\hline \multicolumn{6}{|l|}{ Capital Market Roadmap } \\
\hline Most Likely Exit-IPO & 104 & .48 & .50 & 0 & 1 \\
\hline Most Likely Exit-Trade Sale & 104 & .48 & .50 & 0 & 1 \\
\hline Years to Planned Exit & 104 & 3.86 & 1.15 & 1 & 7 \\
\hline Target Funding & 104 & 1,778,799 AUD & 1,421,268 AUD & 300,000 AUD & 5,000,000 AUD \\
\hline \multicolumn{6}{|l|}{ External Certification } \\
\hline Award & 104 & .17 & .38 & 0 & 1 \\
\hline Government Grant & 104 & .019 & .14 & 0 & 1 \\
\hline Patent & 104 & .20 & .40 & 0 & 1 \\
\hline \multicolumn{6}{|l|}{ Board Experience } \\
\hline \# Board & 104 & 3.61 & 1.02 & 1 & 8 \\
\hline \# Staff & 104 & 7.16 & 12.59 & 0 & 120 \\
\hline \% Board MBA & 104 & 4.47 & 11.62 & 0 & 50 \\
\hline \% Non-Executive Board & 104 & 22.91 & 25.49 & 0 & 75 \\
\hline Years in Business & 104 & 2.63 & 4.92 & 0 & 30 \\
\hline \multicolumn{6}{|l|}{ Risk Level } \\
\hline Equity Offering & 104 & 21.30 & 13.25 & 1.53 & 90 \\
\hline Disclaimer & 104 & .15 & .36 & 0 & 1 \\
\hline $\begin{array}{l}\text { No Disclaimer x } \\
\text { No Financial Forecast }\end{array}$ & 104 & .47 & .50 & 0 & 1 \\
\hline Intended Number of Rounds & 104 & 2.5 & .59 & 1 & 3 \\
\hline
\end{tabular}

Speed of Investing

Funds Raised in Round 1

Parcel Size Round 1

Share Price Round 1

$\begin{array}{lllll}92 & 31,304 \text { AUD } & 20,097 & 5,000 \text { AUD } & \text { 200,000 AUD } \\ 92 & 31,304 \text { AUD } & 20,097 & 5,000 \text { AUD } & \text { 200,000 AUD }\end{array}$


Table IV: Success Determinants of Crowdfunding Projects Measured by Number of Investors

The sample covers 104 crowdfunded projects, and we account for multiple investments by a single investor in a specific start-up. We run zero-inflated negative binomial regressions (using robust standard errors) for the number of investors in a start-up, given over-dispersion (mean: 7.52, variance: 145.18 ) and the fact that 37 start-ups received no funding at all, resulting in a significant number of zeros in our dependent variable. Within the estimation, we control for factors that potentially influence the likelihood of whether a project can attract at least one investor (0/1 outcome via logit model; depicted in the last part of the table with offerings that began before 2009 as a reference category), because these zeros may be generated by an independent process. The full model is shown in Specification 3; exit channel IPO serves as a reference category. Big city fixed effects are dummy variables for Sydney, Melbourne, Brisbane, and Perth. In all specifications, we use offering timing as a potential reason why a start-up received no funding. As a further robustness check (not reported here), we included the additional variables: equity offering, disclaimer x no financial forecast, and no disclaimer $x$ no financial forecast. Our results remain qualitatively stable. ${ }^{* * *},{ }^{* *}$, and $*$ indicate statistical significance at the $1 \%, 5 \%$, and $10 \%$ levels, respectively.

\begin{tabular}{|c|c|c|c|c|c|c|}
\hline & \multicolumn{2}{|c|}{ Specification 1} & \multicolumn{2}{|c|}{ Specification 2} & \multicolumn{2}{|c|}{ Specification 3} \\
\hline & Coefficient & z-Value & Coefficient & z-Value & Coefficient & z-Value \\
\hline (1) Constant & $2.660^{* * *}$ & 3.69 & $2.409^{* * *}$ & 3.28 & -.856 & 1.19 \\
\hline & \multicolumn{6}{|c|}{ Capital Market Roadmap } \\
\hline (2) Most Likely Exit-Trade Sale & -.305 & -1.62 & $-.291^{*}$ & -1.80 & $-.273^{*}$ & -1.84 \\
\hline (3) Most Likely Exit-Others & $-1.889^{* * *}$ & -3.55 & $-2.365^{* * *}$ & -3.54 & $-1.593^{* * *}$ & -3.80 \\
\hline (4) Years to Planned Exit & -.099 & -0.89 & -.054 & -0.41 & .026 & 0.30 \\
\hline (5) Target Funding & .062 & 0.74 & .090 & 1.06 & -.044 & -0.68 \\
\hline & \multicolumn{6}{|c|}{ External Certification } \\
\hline (6) Award & & & .258 & 0.77 & .335 & 1.57 \\
\hline (7) Government Grant & & & .633 & 1.19 & .488 & 1.22 \\
\hline (8) Granted Patent & & & .400 & 1.16 & .150 & 0.46 \\
\hline & \multicolumn{6}{|c|}{ Board Experience } \\
\hline (9) \# Board & & & & & $.360^{* * *}$ & 3.04 \\
\hline (10) \# Staff & & & & & -.001 & -0.09 \\
\hline (11) \% Board MBA & & & & & $.018^{*}$ & 1.80 \\
\hline (12) \% Non-Executive Board Members & & & & & -.004 & -1.06 \\
\hline (13) Years in Business & & & & & -.058 & -1.19 \\
\hline & \multicolumn{6}{|c|}{ Risk Level } \\
\hline (14) Equity Offering & $-.016^{*}$ & -1.71 & $-.018^{* *}$ & -2.49 & $-.018^{* * *}$ & -3.17 \\
\hline (15) Disclaimer x No Financial Forecast & -.182 & -0.71 & -.157 & -0.67 & -.372 & 1.17 \\
\hline (16) No Disclaimer x No Financial Forecast & -.253 & -1.36 & -.234 & -1.24 & -.190 & -0.96 \\
\hline (17) Intended Number of Rounds & .198 & 1.00 & .213 & 1.05 & .093 & 0.38 \\
\hline Year Fixed Effects & YES & & YES & & YES & \\
\hline Industry Fixed Effects & YES & & YES & & YES & \\
\hline Big City Fixed Effects & YES & & YES & & YES & \\
\hline
\end{tabular}


Table IV: Success Determinants of Crowdfunding Projects Measured by Number of Investors—Continued

\begin{tabular}{|c|c|c|c|c|c|c|}
\hline /lnalpha & $-1.344^{* * *}$ & -4.71 & $-1.436^{* * *}$ & -5.14 & $-2.136^{* * *}$ & -5.15 \\
\hline alpha & .261 & & .238 & & .118 & \\
\hline \multicolumn{7}{|l|}{ Inflate } \\
\hline Offering 2009 & $1.234^{*}$ & 1.72 & $1.190^{*}$ & 1.70 & 1.247 & 1.63 \\
\hline Offering 2010 & .487 & 0.71 & .463 & 0.70 & .572 & 0.77 \\
\hline Offering 2011 & .186 & 0.20 & .094 & 0.10 & .419 & 0.46 \\
\hline Constant & $-1.297^{* *}$ & -2.23 & $-1.272^{* *}$ & -2.27 & $-1.386^{* *}$ & -2.19 \\
\hline \# Observation & 104 & & 104 & & 104 & \\
\hline \# Non-Zero Observation & 67 & & 67 & & 67 & \\
\hline \# Zero Observation & 37 & & 37 & & 37 & \\
\hline Log pseudolikelihood & -266.5478 & & -264.1641 & & -252.8581 & \\
\hline Wald $\chi^{2}(20)$ & $604.18^{* * *}$ & & & & & \\
\hline Wald $\chi^{2}(23)$ & & & $2,485.45^{* * * *}$ & & & \\
\hline Wald $\chi^{2}(28)$ & & & & & $349.91^{* * *}$ & \\
\hline
\end{tabular}


Table V: Success Determinants of Crowdfunding Projects Measured by Absolute Funding Amount

The sample covers 104 crowdfunding projects. We run standard OLS regressions (using robust standard errors) to identify the factors that determine absolute funding amount in

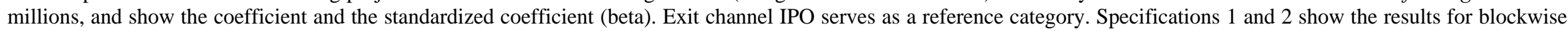
regressions; in specification 3, all blocks are included simultaneously, including year, industry and big city fixed effects. City fixed effects are dummy variables for Sydney, Melbourne, Brisbane, and Perth. ***, **, and * indicate statistical significance at the $1 \%, 5 \%$, and $10 \%$ levels, respectively. Investigating the variance inflation factors reveals no multicollinearity exists, given the mean VIF of 1.65 and all individual values well below the critical value of 5 (see Kutner et al., 2005).

\begin{tabular}{|c|c|c|c|c|c|c|c|c|c|}
\hline & \multicolumn{3}{|c|}{ Specification 1} & \multicolumn{3}{|c|}{ Specification 2} & \multicolumn{3}{|c|}{ Specification 3} \\
\hline & Coefficient & Beta & t-Value & Coefficient & Beta & t-Value & Coefficient & Beta & t-Value \\
\hline (1) Constant & .419 & & 1.63 & .378 & & 1.41 & -.038 & & -0.10 \\
\hline & \multicolumn{9}{|c|}{ Capital Market Roadmap } \\
\hline (2) Most Likely Exit-Trade Sale & -.112 & -.109 & -1.26 & -.124 & -.121 & -1.40 & $\begin{array}{l}.094 \\
\end{array}$ & -.091 & -0.91 \\
\hline (3) Most Likely Exit-Others & -.006 & -.002 & 0.02 & -.056 & -.021 & -0.19 & .006 & -.002 & -0.02 \\
\hline (4) Years to Planned Exit & -.058 & -.129 & -1.29 & -.053 & -.118 & -1.18 & -.030 & -.068 & -0.66 \\
\hline (5) Target Funding & .051 & .140 & 1.27 & .052 & .144 & 1.21 & .022 & .060 & 0.54 \\
\hline & \multicolumn{9}{|c|}{ External Certification } \\
\hline (6) Award & & & & .060 & .044 & 0.49 & -.074 & -.055 & 0.59 \\
\hline (7) Government Grant & & & & .265 & .071 & 0.66 & .112 & .030 & 0.32 \\
\hline (8) Granted Patent & & & & .067 & .052 & 0.71 & .080 & .062 & 0.74 \\
\hline & \multicolumn{9}{|c|}{ Board Experience } \\
\hline (9) \# Board & & & & & & & $.126^{*}$ & $.249^{*}$ & 1.93 \\
\hline (10) \# Staff & & & & & & & .004 & .101 & 1.32 \\
\hline (11) \% Board MBA & & & & & & & -.002 & -.047 & -0.55 \\
\hline (12) \% Non-Executive Board Members & & & & & & & -.003 & -.124 & -1.38 \\
\hline (13) Years in Business & & & & & & & -.008 & -.075 & -1.01 \\
\hline & \multicolumn{9}{|c|}{ Risk Level } \\
\hline (14) Equity Offering & -.003 & -.071 & -0.63 & -.004 & -.100 & -0.96 & -.002 & -.055 & -0.58 \\
\hline (15) Disclaimer x No Financial Forecast & -.148 & -.105 & -1.00 & -.135 & -.095 & -0.90 & .041 & .029 & -0.25 \\
\hline (16) No Disclaimer x No Financial Forecast & $-.233^{* *}$ & $-.227^{* *}$ & -2.59 & $-.227^{* *}$ & $-.221^{* * 4}$ & -2.46 & $-.206^{* *}$ & $-.200^{* *}$ & -2.07 \\
\hline (17) Intended Number of Rounds & $.131^{*}$ & $.151^{*}$ & 1.87 & $.137^{*}$ & $.157^{*}$ & 1.86 & .078 & .090 & 1.01 \\
\hline Year Fixed Effects & YES & & & YES & & & YES & & \\
\hline Industry Fixed Effects & YES & & & YES & & & YES & & \\
\hline Big City Fixed Effects & YES & & & YES & & & YES & & \\
\hline \#Observation & 104 & & & 104 & & & 104 & & \\
\hline $\begin{array}{c}F(20,83) \\
{\left[R^{2}\right]}\end{array}$ & $\begin{array}{c}1.80^{* *} \\
{[46.50 \%]}\end{array}$ & & & & & & & & \\
\hline $\begin{array}{c}F(23,80) \\
{\left[R^{2}\right]}\end{array}$ & & & & $\begin{array}{c}1.58^{*} \\
{[47.34 \%]}\end{array}$ & & & & & \\
\hline $\begin{array}{c}F(28,75) \\
{\left[R^{2}\right]}\end{array}$ & & & & & & & $\begin{array}{c}1.60^{*} \\
{[52.90 \%]}\end{array}$ & & \\
\hline
\end{tabular}


Table VI: Determinants of the Speed of Capital Allocation

The sample covers ninety-two crowdfunded projects, of which nineteen successfully completed their first financing round (i.e., nineteen entered a second round of financing after

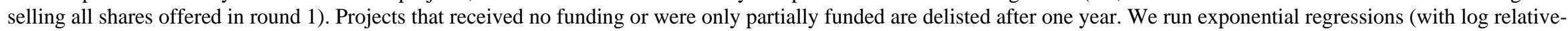

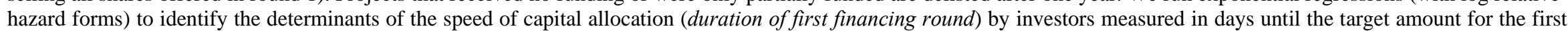
round is raised. Exit channel IPO serves as a reference category. Specification 3 represents the full model. Big city fixed effects are dummy variables for Sydney, Melbourne, Brisbane, and Perth. ***, **, and * indicate statistical significance at the $1 \%, 5 \%$, and $10 \%$ levels, respectively.

\begin{tabular}{|c|c|c|c|c|c|c|}
\hline & \multicolumn{2}{|c|}{ Specification 1} & \multicolumn{2}{|c|}{ Specification 2} & \multicolumn{2}{|c|}{ Specification 3} \\
\hline & Coefficient & z-Value & Coefficient & $z$-Value & Coefficient & $\mathrm{z}$-Value \\
\hline (1) Constant & $-15.440^{* * * *}$ & -4.56 & $-14.612^{* * *}$ & -3.86 & $-21.1851^{* * *}$ & -3.15 \\
\hline & \multicolumn{6}{|c|}{ Capital Market Roadmap } \\
\hline (2) Most Likely Exit-Trade Sale & .848 & 1.07 & -.934 & 1.02 & -1.194 & 1.35 \\
\hline (3) Most Likely Exit-Others & -.273 & -0.18 & -.354 & -0.21 & -.734 & -0.38 \\
\hline (4) Years to Planned Exit & -.377 & -1.17 & -.461 & -1.18 & -.456 & -1.03 \\
\hline (5) Target Funding & -.073 & 0.26 & -.033 & -0.09 & -.034 & -0.09 \\
\hline & \multicolumn{6}{|c|}{ External Certification } \\
\hline (6) Award & & & .453 & 0.57 & .429 & 0.53 \\
\hline (7) Government Grant & & & -1.380 & -0.56 & -2.062 & -0.81 \\
\hline (8) Granted Patent & & & -.154 & -0.19 & -0.954 & -1.01 \\
\hline & \multicolumn{6}{|c|}{ Board Experience } \\
\hline (9) \# Board & & & & & .676 & 1.05 \\
\hline (10) \# Staff & & & & & -.101 & -0.76 \\
\hline (11) \% Board MBA & & & & & $.095^{*}$ & 1.84 \\
\hline (12) \% Non-Executive Board Members & & & & & .006 & 0.31 \\
\hline (13) Years in Business & & & & & $.209^{* *}$ & 2.20 \\
\hline & \multicolumn{6}{|c|}{ Risk Level } \\
\hline (14) Equity Offering & $-.146^{* * *}$ & -3.29 & $-.141^{* * *}$ & -3.07 & $-.166^{* * *}$ & -2.98 \\
\hline (15) Disclaimer x No Financial Forecast & -.450 & -0.49 & -.672 & -0.67 & .725 & -0.72 \\
\hline (16) No Disclaimer x No Financial Forecast & $-2.170^{* * *}$ & -2.71 & $-2.286^{* *}$ & -2.45 & $-3.325^{* * *}$ & -3.32 \\
\hline (17) Intended Number of Rounds & $1.407^{*}$ & 1.87 & $1.384^{*}$ & 1.77 & $2.848^{* *}$ & 2.44 \\
\hline (18) Parcel Size & $>.000^{* * * *}$ & 3.31 & $>.000^{* * *}$ & 2.95 & $>.000^{* * *}$ & 3.31 \\
\hline (19) Share Price & -4.871 & -1.55 & -3.815 & -1.10 & -.989 & -0.26 \\
\hline Year Fixed Effects & YES & & YES & & YES & \\
\hline Industry Fixed Effects & YES & & YES & & YES & \\
\hline Big City Fixed Effects & YES & & YES & & YES & \\
\hline \# Subjects & 92 & & 92 & & 92 & \\
\hline \# Successful Completion of Financing Round I & 19 & & 19 & & 19 & \\
\hline$L R \chi^{2}$ & $57.72^{* * * *}$ & & $58.21^{* * * *}$ & & $65.92^{* * *}$ & \\
\hline Log likelihood & -45.416 & & -45.167 & & -41.315 & \\
\hline
\end{tabular}




\section{Appendix}

Table A: Variable Definitions

This table gives a detailed description of the data-gathering process and the calculation method for all variables.

Variable Name

\begin{tabular}{|c|c|}
\hline \multicolumn{2}{|r|}{ Dependent Variables } \\
\hline Funding Amount & Absolute funding amount in millions AUD. \\
\hline Number of Investors & $\begin{array}{l}\text { Total number of individual investors in a start-up. Adjusted for multiple } \\
\text { investments by single investors. }\end{array}$ \\
\hline $\begin{array}{l}\text { Duration of First } \\
\text { Financing Round }\end{array}$ & $\begin{array}{l}\text { The number of days from the opening day for investors to the day the } \\
\text { targeted amount is raised. If the targeted amount is not met, the project will } \\
\text { be delisted from the platform after one year. }\end{array}$ \\
\hline \multicolumn{2}{|r|}{ Capital Market Roadmap } \\
\hline Most Likely Exit-IPO & Planed exit channel is an IPO. \\
\hline $\begin{array}{l}\text { Most Likely Exit-Trade } \\
\text { Sale }\end{array}$ & Planed exit channel is a trade sale. \\
\hline Most Likely Exit-Other & Planed exit channel is an LBO, reverse takeover, or not indicated. \\
\hline Target Funding & Pursued target funding amount in millions AUD. \\
\hline Years to Planned Exit & $\begin{array}{l}\text { The years to planned exit of a start-up at the time of offering, or not } \\
\text { announced because there is no obligation. This number is exhibited in the } \\
\text { detailed company overview page. }\end{array}$ \\
\hline \multicolumn{2}{|r|}{ External Certification } \\
\hline Award & $\begin{array}{l}\text { Dummy variable indicating whether a start-up or a start-up’s product } \\
\text { received an award. The variable equals } 1 \text { if so, and } 0 \text { otherwise. }\end{array}$ \\
\hline Government Grant & Dummy variable indicating whether a start-up received government grants. \\
\hline Granted Patent & $\begin{array}{l}\text { Dummy Variable indicating whether a start-up quotes a granted patent in an } \\
\text { offering document. The variable equals } 1 \text { if so, and } 0 \text { otherwise. }\end{array}$ \\
\hline
\end{tabular}

\section{Description and Calculation}




\section{Table A: Variable Definitions-Continued}

Board Experience

\begin{tabular}{|c|c|}
\hline \# Board & Number of directors on a start-up’s board. \\
\hline \# Staff & $\begin{array}{l}\text { Total number of staff employed by a start-up at the time of offering. This } \\
\text { number is exhibited in the detailed company overview page. }\end{array}$ \\
\hline$\%$ Board MBA & Percentage of MBA graduates among the executive directors of the board. \\
\hline \% Non-Executive Board & Percentage of non-executive directors on a company’s board. \\
\hline Years in Business & $\begin{array}{l}\text { Number of years a start-up has been in business at the time of offering. This } \\
\text { number is exhibited in the detailed company overview page. }\end{array}$ \\
\hline \multicolumn{2}{|r|}{ Risk Level } \\
\hline Equity Offering & $\begin{array}{l}\text { Percentage of equity that a start-up plans to sell in an offering prior to the } \\
\text { offering. This number is exhibited in the detailed company overview page. }\end{array}$ \\
\hline $\begin{array}{l}\text { Disclaimer x No Financial } \\
\text { Forecast }\end{array}$ & $\begin{array}{l}\text { Dummy variable indicating whether a start-up includes a disclaimer in its } \\
\text { offering document that states that the entrepreneurs do not provide financial } \\
\text { forecasts for legal reasons. The variable equals } 1 \text { if a disclaimer is included } \\
\text { but without a financial forecast, and } 0 \text { otherwise. }\end{array}$ \\
\hline $\begin{array}{l}\text { No Disclaimer x No } \\
\text { Financial Forecast }\end{array}$ & $\begin{array}{l}\text { Dummy variable indicating that a company provides neither a financial } \\
\text { forecast nor a disclaimer in the offering documents. }\end{array}$ \\
\hline $\begin{array}{l}\text { Intended Number of } \\
\text { Rounds }\end{array}$ & $\begin{array}{l}\text { Set number of rounds by founders in the offering documents in which they } \\
\text { want to raise money. The number of rounds can vary between one and } \\
\text { three. }\end{array}$ \\
\hline \multicolumn{2}{|r|}{ Speed of Investing } \\
\hline Parcel Size & $\begin{array}{l}\text { Minimum investment amount in AUD; investors can purchase only whole } \\
\text { numbers. }\end{array}$ \\
\hline Share Price & Price investors must pay per share. \\
\hline
\end{tabular}




\section{Appendix B: Correlation Matrix}

This table shows the Pearson correlation coefficients for the variables in Table III-p-values are given in parentheses below the coefficients. ***, **, and * indicate statistical significance at the $1 \%, 5 \%$, and $10 \%$ levels, respectively.

\begin{tabular}{|c|c|c|c|c|c|c|c|c|c|c|c|c|c|}
\hline & (1) & (2) & (3) & (4) & (5) & (6) & (7) & (8) & (9) & (10) & (11) & (12) & (13) \\
\hline $\begin{array}{l}\text { Funding } \\
\text { Amount (1) }\end{array}$ & 1.0000 & & & & & & & & & & & & \\
\hline \# Staff (2) & $\begin{array}{c}0.0453 \\
(0.6483)\end{array}$ & 1.0000 & & & & & & & & & & & \\
\hline $\begin{array}{c}\text { Years in } \\
\text { Business (3) }\end{array}$ & $\begin{array}{l}-0.0696 \\
(0.4824)\end{array}$ & $\begin{array}{l}0.4092^{* * *} \\
(0.0000)\end{array}$ & 1.0000 & & & & & & & & & & \\
\hline $\begin{array}{c}\text { Equity } \\
\text { Offering (4) }\end{array}$ & $\begin{array}{l}-0.1405 \\
(0.1549)\end{array}$ & $\begin{array}{c}0.0395 \\
(0.6906)\end{array}$ & $\begin{array}{c}0.0453 \\
(0.6481)\end{array}$ & 1.0000 & & & & & & & & & \\
\hline \# Board (5) & $\begin{array}{l}0.2604^{* * *} \\
(0.0076)\end{array}$ & $\begin{array}{l}0.2566^{* * *} \\
(0.0086)\end{array}$ & $\begin{array}{c}0.0989 \\
(0.3178)\end{array}$ & $\begin{array}{l}-0.1030 \\
(0.2983)\end{array}$ & 1.0000 & & & & & & & & \\
\hline $\begin{array}{c}\text { Years to } \\
\text { Planned Exit (6) }\end{array}$ & $\begin{array}{l}-0.2693^{* * *} \\
(0.0057)\end{array}$ & $\begin{array}{l}0.0719^{*} \\
(0.4682)\end{array}$ & $\begin{array}{l}0.2270^{* *} \\
(0.0205)\end{array}$ & $\begin{array}{l}0.1622^{*} \\
(0.0999)\end{array}$ & $\begin{array}{l}-0.1068 \\
(0.2805)\end{array}$ & 1.0000 & & & & & & & \\
\hline $\begin{array}{l}\% \text { Non-Executive } \\
\text { Board (7) }\end{array}$ & $\begin{array}{l}-0.0881 \\
(0.3739)\end{array}$ & $\begin{array}{l}0.1781^{*} \\
(0.0705)\end{array}$ & $\begin{array}{c}0.0943 \\
(0.3409)\end{array}$ & $\begin{array}{c}0.1763^{*} \\
(0.0735)\end{array}$ & $\begin{array}{c}0.0771 \\
(0.4364)\end{array}$ & $\begin{array}{c}0.1274 \\
(0.1976)\end{array}$ & 1.0000 & & & & & & \\
\hline \% Board MBA (8) & $\begin{array}{l}-0.0714 \\
(0.4713)\end{array}$ & $\begin{array}{l}-0.1045 \\
(0.2913)\end{array}$ & $\begin{array}{l}-0.0439 \\
(0.6579)\end{array}$ & $\begin{array}{c}0.0276 \\
(0.7807)\end{array}$ & $\begin{array}{l}-0.0629 \\
(0.5256)\end{array}$ & $\begin{array}{c}0.0233 \\
(0.8147)\end{array}$ & $\begin{array}{c}-0.3130^{* * *} \\
(0.0012)\end{array}$ & 1.0000 & & & & & \\
\hline $\begin{array}{c}\text { Number of } \\
\text { Investors (9) }\end{array}$ & $\begin{array}{l}0.8611^{* * *} \\
(0.0000)\end{array}$ & $\begin{array}{c}0.0288 \\
(0.7715)\end{array}$ & $\begin{array}{l}-0.1077 \\
(0.2765)\end{array}$ & $\begin{array}{l}-0.2013^{* *} \\
(0.0405)\end{array}$ & $\begin{array}{l}0.2534^{* * *} \\
(0.0094)\end{array}$ & $\begin{array}{l}-0.2833^{* * *} \\
(0.0036)\end{array}$ & $\begin{array}{l}-0.1205 \\
(0.2232)\end{array}$ & $\begin{array}{c}0.0050 \\
(0.9599)\end{array}$ & 1.0000 & & & & \\
\hline $\begin{array}{l}\text { Parcel Size } \\
\text { Round } 1 \text { (10) }\end{array}$ & $\begin{array}{c}0.1413 \\
(0.1524)\end{array}$ & $\begin{array}{l}-0.0489 \\
(0.6222)\end{array}$ & $\begin{array}{l}-0.0863 \\
(0.3839)\end{array}$ & $\begin{array}{c}0.0852 \\
(0.3896)\end{array}$ & $\begin{array}{l}-0.0217 \\
(0.8267)\end{array}$ & $\begin{array}{l}-0.1599 \\
(0.1049)\end{array}$ & $\begin{array}{l}-0.0666 \\
(0.5019)\end{array}$ & $\begin{array}{c}0.1363 \\
(0.1677)\end{array}$ & $\begin{array}{c}0.0793 \\
(0.4237)\end{array}$ & 1.0000 & & & \\
\hline $\begin{array}{l}\text { Share Price } \\
\text { Round } 1 \text { (11) }\end{array}$ & $\begin{array}{l}0.5532^{* * *} \\
(0.0000)\end{array}$ & $\begin{array}{c}0.0463 \\
(0.6408)\end{array}$ & $\begin{array}{l}-0.0194 \\
(0.8453)\end{array}$ & $\begin{array}{l}-0.1942^{* *} \\
(0.0482)\end{array}$ & $\begin{array}{c}0.1634 \\
(0.0974)\end{array}$ & $\begin{array}{l}-0.1789^{*} \\
(0.0693)\end{array}$ & $\begin{array}{c}0.0165 \\
(0.8679)\end{array}$ & $\begin{array}{l}-0.0511 \\
(0.6067)\end{array}$ & $\begin{array}{l}0.5694^{* * *} \\
(0.0000)\end{array}$ & $\begin{array}{l}0.2264^{* *} \\
(0.0208)\end{array}$ & 1.0000 & & \\
\hline $\begin{array}{l}\text { Funds Raised in } \\
\text { Round } 1 \text { (12) }\end{array}$ & $\begin{array}{l}0.5600^{* * *} \\
(0.0000)\end{array}$ & $\begin{array}{l}-0.0065 \\
(0.9477)\end{array}$ & $\begin{array}{l}-0.1749^{*} \\
(0.0757)\end{array}$ & $\begin{array}{c}0.0562 \\
(0.5710)\end{array}$ & $\begin{array}{c}0.0712 \\
(0.4725)\end{array}$ & $\begin{array}{l}-0.1173 \\
(0.2356)\end{array}$ & $\begin{array}{l}-0.2126^{* *} \\
(0.0303)\end{array}$ & $\begin{array}{c}0.0742 \\
(0.4540)\end{array}$ & $\begin{array}{l}0.5446^{* * *} \\
(0.0000)\end{array}$ & $\begin{array}{c}0.1015 \\
(0.3052)\end{array}$ & $\begin{array}{c}0.1007 \\
(0.3090)\end{array}$ & 1.0000 & \\
\hline $\begin{array}{l}\text { Funding Sought } \\
\text { Round } 1 \text { (13) }\end{array}$ & $\begin{array}{l}0.2226^{* *} \\
(0.0232\end{array}$ & $\begin{array}{c}0.1397 \\
(0.1572)\end{array}$ & $\begin{array}{l}-0.0386 \\
(0.6971)\end{array}$ & $\begin{array}{c}0.0797 \\
(0.4213)\end{array}$ & $\begin{array}{c}0.1467 \\
(0.1373)\end{array}$ & $\begin{array}{l}-0.0275 \\
(0.7820)\end{array}$ & $\begin{array}{l}0.1625^{*} \\
(0.0993)\end{array}$ & $\begin{array}{l}-0.1210 \\
(0.2212)\end{array}$ & $\begin{array}{l}0.2376^{* *} \\
(0.0152)\end{array}$ & $\begin{array}{l}-0.1621 \\
(0.1003)\end{array}$ & $\begin{array}{c}0.0420 \\
(0.6717)\end{array}$ & $\begin{array}{c}0.0316 \\
(0.7500)\end{array}$ & 1.0000 \\
\hline
\end{tabular}




\section{Appendix C: ASSOB Screenshots}

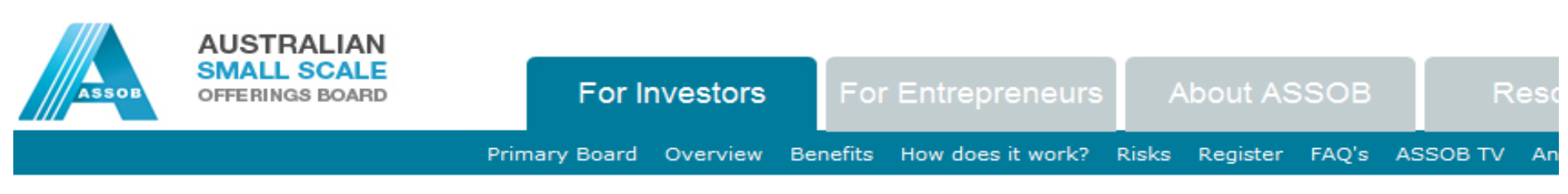

\section{Primary Board}

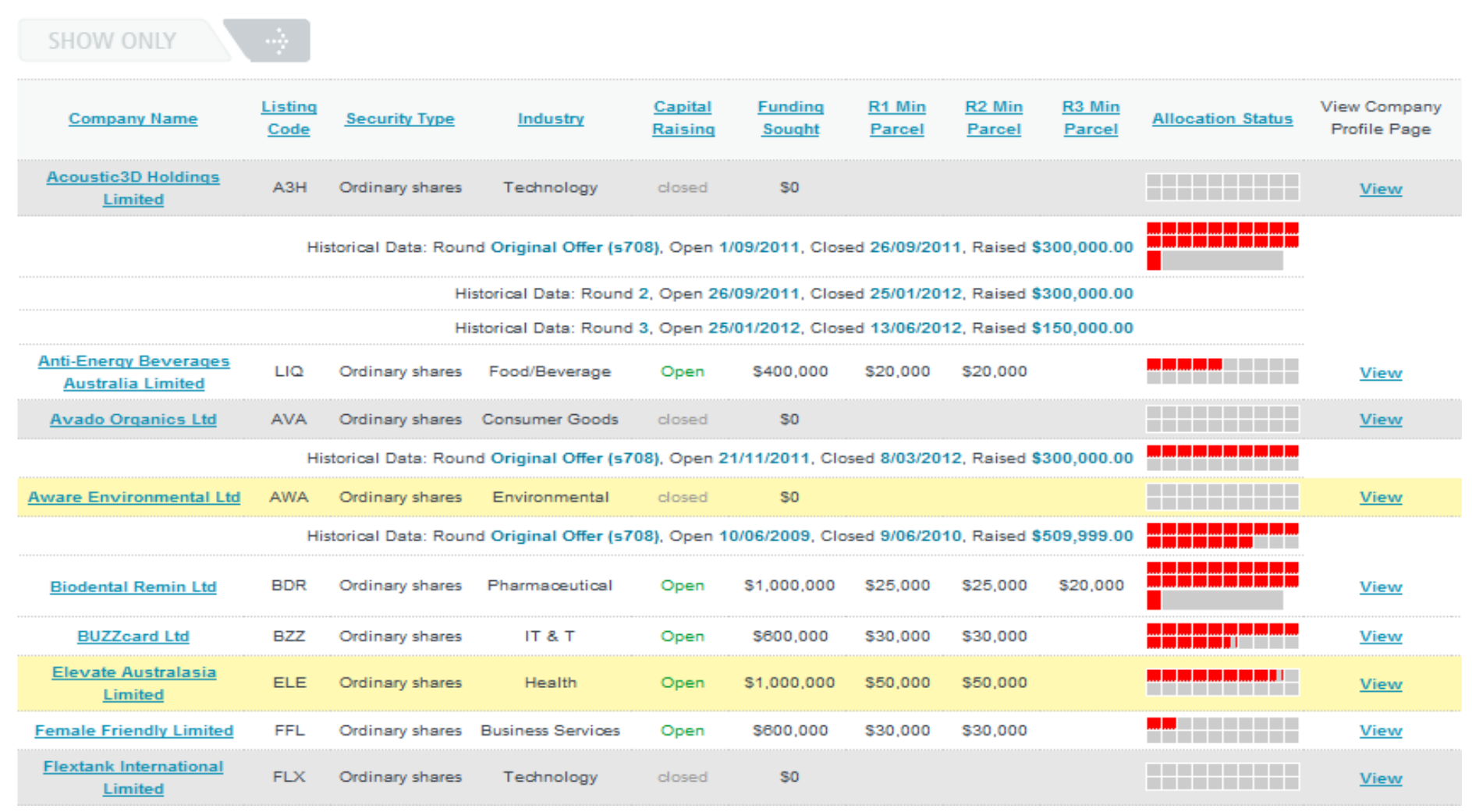

(Screenshot 1, Primary Board) 
Gerrit Ahlers logged in my account | logout Board Status Closed

Overview Benefits How does it work? Risks Register FAQ's ASSOB TV Announcements

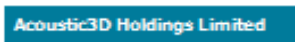

Anti-Energy Beverages Australio

Limited

Avado Onganios Ltt

Aware Environmental Ltd

Biodental Remin Ltt

suzzcard Ltd

Elevate Australasia Limited

Female Friendly Limited

Flextank Intemational Limited

Forrester Cohen Intemational

Group Limited

ICT123 Holdings Ltt

Ipowow! Ltt

Keyhole IIG Limited

KPG Pacific Properties Ltd

Kudos Knowledge Limited

Lahris Ltd

Little Nest Fumishings Limited

U Hooker Intemational Limited

Localite Limited

Manifesto of Light Intematione

Ltd

Mercurien Limited

Moneysoft Limited

Ocular Robotics Limited

Opmantek Lttd

Oswill Limited

Photomerchant Lto

\begin{tabular}{|l|l|l|l|l|l|l|}
\hline About & Bid / Sell & Contact & Sales Tracker & People & Blog & Q\&A \\
\hline
\end{tabular}

Share Sales Tracker - Acoustic3D Holdings Limited

Status > OPEN FOR SECONDARY SALES

* Most recent issue or sale on top

\begin{tabular}{|c|c|c|c|c|}
\hline Volume & Price & Value & Movement since ASSOB listing & Type \\
\hline $1,000,000$ & $\$ 0.10$ & $\$ 100,000$ & $\Delta 68.67 \%$ & Primary \\
\hline 500,000 & $\$ 0.10$ & $\$ 50,000$ & $\Delta 68.67 \%$ & Primary \\
\hline $1,500,000$ & $\$ 0.08$ & $\$ 120,000$ & $\Delta 33.33 \%$ & Primary \\
\hline 375,000 & $\$ 0.08$ & $\$ 30,000$ & $\Delta 33.33 \%$ & Primany \\
\hline 375,000 & $\$ 0.08$ & $\$ 30,000$ & $\boldsymbol{\Delta} 33.33 \%$ & Primary \\
\hline 375,000 & $\$ 0.08$ & $\$ 30,000$ & $\boldsymbol{\Delta} 33.33 \%$ & Primary \\
\hline 375,000 & $\$ 0.08$ & $\$ 30,000$ & $\boldsymbol{\Delta} 33.33 \%$ & Primary \\
\hline 375,000 & $\$ 0.08$ & $\$ 30,000$ & $\boldsymbol{\Delta} 33.33 \%$ & Primary \\
\hline 375,000 & $\$ 0.08$ & $\$ 30,000$ & $\boldsymbol{\Delta} 33.33 \%$ & Primary \\
\hline $3,000,000$ & $\$ 0.06$ & $\$ 180,000$ & $00.00 \%$ & Primary \\
\hline 500,000 & $\$ 0.06$ & $\$ 30,000$ & $00.00 \%$ & $\underline{\text { Primary }}$ \\
\hline 500,000 & $\$ 0.08$ & $\$ 30,000$ & $00.00 \%$ & Primary \\
\hline 500,000 & $\$ 0.06$ & $\$ 30,000$ & $00.00 \%$ & $\underline{\text { Primary }}$ \\
\hline 500,000 & $\$ 0.06$ & $\$ 30,000$ & $00.00 \%$ & Primary \\
\hline
\end{tabular}

(Screenshot 2, Bid/Sell) 